\title{
The B2Com Relationship: An Empirical Study of the Measure of Relationship Quality in a Business-to-Community Relationship
}

\author{
Oluyomi Abayomi Osobajo ${ }^{1}$, David Moore ${ }^{1}$ \\ ${ }^{1}$ The Scott Sutherland School of Architecture \& Built Environment, The Robert Gordon University, Aberdeen, \\ Scotland, United Kingdom
}

Correspondence: Oluyomi Abayomi Osobajo, The Scott Sutherland School of Architecture \& Built Environment, The Robert Gordon University, Aberdeen, Scotland, United Kingdom.

\author{
Received: May 16, 2017 \\ Accepted: June 13, $2017 \quad$ Online Published: June 19, 2017 \\ doi:10.5539/ibr.v10n7p118 \\ URL: https://doi.org/10.5539/ibr.v10n7p118
}

\begin{abstract}
The quality of relationship between Oil Producing Companies (OPC) and their Host Communities (HC) within the Niger Delta Region of Nigeria (NDRN) is a source of concern for different stakeholders such as the practitioners, government, communities, and OPC. Scholars in the field of marketing have studied relationship quality in different contexts, such as business-to-business, business-to-customer, customer-to-business, and interpersonal relationship. In this paper, the authors build on existing studies to develop a new relationship framework in a business-to-community (B2Com) context, intended to assess the degree of relationship quality between a business and its host community. The framework is supported by the results of a qualitative research study conducted using an in-depth semi-structured interview approach in exploring and assessing the various relationship elements and constructs impacting on the quality of a relationship developed between an OPC business and its host community in the Niger Delta of Nigeria. The findings showed that activity links, resources ties, actor bond, mutual benefit, communication, control mutuality, mutual goal and culture are the main antecedents of relationship quality, while trust, satisfaction, and commitment are the essential outcomes of relationship quality. The findings also showed that there is a linear relationship between trust, satisfaction and commitment.
\end{abstract}

Keywords: relationship, relationship marketing, relationship elements, relationship quality, community, oil producing company, oil and gas industry

\section{Introduction}

The concept of relationship emerges from the field of relationship marketing (Christopher et al., 1991; Gummesson, 1995; Buttle, 1996), which is focused on "attracting, maintaining and, in multi service organisations, enhancing customer relationships" (Berry 1983, p. 25). Likewise, Gronroos (1994, p. 355) added that relationship marketing is about "establishing, maintaining, and enhancing relationships with customers and other partners, at a profit, so that the objectives of the parties involved are met. This is achieved by a mutual exchange and fulfilment of promises". Christopher et al (1991), and Rust et al (2004) argued further that the focus within the relationship marketing paradigm has shifted completely from a transactional paradigm to a relationship paradigm. The relationship paradigm focuses on having a long-term orientation that will result in a win-win situation among relationship parties, while the transactional paradigm is merely a one-off exchange between relationship parties. Hence, these views and opinions suggest that relationship marketing can be termed as a process by which parties to a relationship obtain what they desire through creating and exchanging value with one another (Kotler and Armstrong, 2010).

Researchers have predominantly studied relationship quality through a focus on business-to-business (B2B), business-to-customer (B2C), customer-to-business (C2B), and interpersonal relationships. The development of a business-to-community (B2Com) relationship has not received any attention from researchers. Indeed, as Gummesson (2002) suggested that there are 30 different relationship types that need to be evaluated and, not surprisingly, scholars have concluded that there are many types of relationships that should be examined (Athanassopoulou, 2006). This research study intends to empirically explore and understand the quality of relationship in a B2Com context. A B2Com relationship refers to a relationship developed between a business and its host community in which it operates. This supports the assertion that, in an increasingly competitive business environment, a business must give attention to its various stakeholders such as the community that could support 
or hinder the realisation of business objectives (Freeman, 1984). Hence, the development of a B2Com relationship is important for those businesses whose achievement of their objectives is strongly influenced by the community in which they operate.

This research study presented here commenced with a discussion on the importance of a relationship between a business and its host community, and subsequently conducted a literature review to determine what is a relationship, relationship elements, relationship quality and relationship quality constructs as identified by existing literature. Thereafter, the research findings are discussed and propositions are formulated.

\section{The Importance of the Oil Producing Company (OPC) and Host Community (HC) Relationship}

Nigeria as a nation is highly dependent on crude oil as a major source of her income (Akins, 1973; Beckman, 1982; Khan, 1994; Ellis, 2003; Watts, 2004; Ross, 2012; Kadafa, 2012; Esfahani et al., 2014; Arezki and Blanchard, 2015; Ikein, 2016). Ross (2003), Adenugba and Dipo (2013), Rhodes and Suleiman (2013), and Ikein (2016) noted that Nigeria has consistently earned over $90 \%$ of her revenue from crude oil since commercial production commenced in the 1970s. In addition, Ikelegbe (2001), Eweje (2006), and Omofonmwan and Odia (2009) argued that a larger percentage of the exploration and production (EP) activities within the Nigerian oil and gas industry (NOGI) take place in the Niger Delta region of Nigeria (NDRN). Hence, making the NDRN a region to be reckoned with (Frynas, 2001).

The rapid and continuous deterioration of the NDRN has been widely noted by scholars and practitioners (Puyate and Rim-Rukeh, 2008; Giraud and Renouard, 2010; Renouard, 2010; Renouard and Lado, 2012; Ubani and Onyejekwe, 2013). This decline is evidenced by po verty among the communities in the region (Nriagu et al., 2016), poorly planned and managed coastal and community development (Ubani and Onyejekwe, 2013), and a poor educational system (Osaghae et al., 2007; Omofonmwan and Odia, 2009; Onemolease and Alakpa; 2009; Nyengidiki and Allagoa, 2011). In addition, the region is facing worsened environmental conditions (Ikporukpo, 1983; Watts, 2001; Puyate and Rim-Rukeh, 2008), increases in social inequality (Renouard, 2011), water pollution, reductions in wildlife and fisheries, soil degradation (Chokor, 2004), and generally worsened economies and health condition (Giraud and Renouard, 2010; Renouard and Lado, 2012; Adelabu, 2012). Kadafa (2012), Ite et al (2013), and Ebegbulem et al (2013) acknowledged that these outcomes are attributable to crude oil exploration and production (EP) activities and by association, the presence of OPCs in the region. Hence, the region has been the subject of continuous conflicts and violence between the NDRN communities and the OPCs (Aghedo, 2013; Obi, 2014).

Among the different types of community (i.e. host community, impacted community, transit community, and terminal community) in the NDRN, the Host Community (HC) is the most highly affected. This is because the HC serve as the host for OPC's EP operations and activities. Elum et al (2016, p. 12880) referred to HC as "the places (on land) or communities where oil wells are sited". The effects of OPC presence on the HC is evidenced in the adverse environmental effects on forest, soils and water bodies in HC in the NDRN (Worgu, 2000). Likewise, Eweje (2006) asserted that the commencement of OPC's EP activities led to the emergence of environmental problems in the HC. Apata (2010) added that OPC presence within the region led to the beginning of a continuous environmental degradation that has resulted in a culminating poverty, which is depriving the $\mathrm{HC}$ of its resource benefits. Equally, Idemudia (2016) noted that the $\mathrm{HC}$ has experienced undermined human development due to the presence of OPC. Olobaniyi and Omo-Irabor (2016) stated that the HC has experienced declining health and environmental conditions since the arrival of the OPC, while Elum et al (2016) concluded that the HC has experienced disastrous and persistent effects of gas flaring on its agricultural produce.

Scholars (e.g. Idemudia, 2014b; Aghedo and Osumah, 2014; Osaghae, 2015) have likened the NDRN to a war zone since the 1990's due to the continuous conflict between the OPC and HC. Idemudia (2014a) stated that the OPC and HC relationship began to deteriorate into conflict and violence in the 1980's. Idemudia (2007) asserted that the $\mathrm{HC}$ perceived their relationship with the OPC as "negative" because they (the HC) believe they are considered as an obstacle by the OPC to the successful exploration and production of crude oil in the region. Therefore, OPC are regarded as increasingly viewing the $\mathrm{HC}$ as a risk to be managed (Idemudia, 2014a). In addition, Elum et al (2016, p. 12881) asserted that the "HC are relegated to the background in decision making as it affects oil exploration and exploitation in their territory". These standpoints necessitate the assessment of the relationship between the OPC and HC (Idemudia, 2014b).

\section{What is a Relationship?}

There is no consensus among scholars of a single definition on what a relationship really is; the concept has varying definitions in different disciplines. Hinde (1979, 1981), cited in Blumstein \& Kollock (1988, p. 468) within the social psychology discipline, define a relationship as "a series of related interactions, each affected by 
past episodes, and in turn affecting future interactions". This definition considers a relationship to be symbiotic in nature; the behaviour of people or groups within the relationship affects each other. Likewise, Hakansson and Snehota (1995, p. 25) define a relationship as "a mutually oriented interaction between two reciprocally committed parties". They regard mutual orientation and commitment as an essential aspect of the interactions between relationship parties. In addition, it could be argued that the presence of mutual orientation and commitment connotes dependency between them, such that the existence of one party depends on the survival of the other party.

Within the communication discipline, a relationship is referred to as a link existing between two or more people with a mutual purpose over a period of time (Coombs, 2001). Relationship in this respect is considered a two-way route where parties involved need to be aware of each other and their respective interaction.

Ledingham and Bruning (1998, p. 62), within the public relations discipline, define a relationship as being the "state which exists between an organisation and its key publics in which the actions of either entity impact the economic, social, political, and/or cultural wellbeing of the other entity". Broom et al (2000) added that a relationship is as a series comprising interaction, transaction, exchange, and linkage between the parties involved. They claim that there exist different properties between the people involved and the relationship itself. This leads to a distinction between the attributes, perception and identities of the people involved in the relationship. Ledingham (2003, p. 190) asserted that an effective theory of relationship should encourage collaboration because "effectively managing organizational-public relationships around common interests and shared goals, over time, results in mutual understanding and benefit for interacting organizations and publics".

However, it is worth stating that a significant body of research and literature on the meaning of "relationship" adopts the standpoint of the organisation and thus incorporates some level of corporate biasness in it. From this standpoint, people who are not in support of the organisation's objectives are pictured adversely, and the organisation is required to please them. Hallahan $(2004$, p. 775$)$ concluded that a relationship involves "routinized, sustained patterns of behaviour by individuals related to their involvement with an organisation ... and thus are part of a total organisational-public relationship". Even though all these scholars have different approaches to the definition of a relationship, they all seem to view relationship as a form of interaction, which often arises between two or more parties because of the outcome interdependence.

\subsection{Types of Relationship}

The evaluation of types of relationship is important in order to assess the relationship that exists between relationship parties. It provides and describes the features of a relationship and the expected relationship outcomes (Grunig, 2002). The types of relationships will be discussed under the following subheadings: exchange or discrete transaction relationship, and communal or relational exchange relationship.

\subsubsection{Exchange Relationship}

In an exchange relationship, one relationship party provides benefit to another in return for something that is of comparable value to them (Grunig, 2002). The comparable value provided could be a future expectation or something for immediate exchange. This suggests that relationship parties are only willing to give benefits to one another because there is a benefit of perceived comparable value to receive in return. This type of relationship is also referred to as a discrete transaction relationship. MacNeil (1980, p. 60), asserts that "the archetype of discrete transaction is manifested by money on one side and an easily measured commodity on the other". Discrete transaction relationships are characterised by narrow content and limited communications. For example, a purchase of unleaded gasoline made by a passing customer at a filling station. In addition, a party receiving a benefit in an exchange relationship must have incurred an obligation in the past or should be ready to return a favour in the future (Hung, 2005). Hence, there is an uncertain time dimension component in this relationship. Exchange relationship is the foundation on which relationship marketing as a concept was formed (Grunig, 2002). However, an exchange relationship is not suitable for all of an organisation's stakeholders. For example, the public (i.e. the community) expect more benefit from an organisation than the benefit typically expected from the public by that organisation.

\subsubsection{Communal Relationship}

In a communal relationship, relationship parties "are willing to provide benefits to the other because they are concerned for the welfare of the other - even when they believe they might not get anything in return" (Grunig, 2002). This relationship type is viewed as a departure from the discrete transaction relationship, which suggests that the parties involved have no expectation of an exchange of benefits, but merely provide benefits in a philanthropic manner (Clark \& Mils, 1993). Communal relationship is also referred to as a relational exchange relationship (Dwyer et al., 1987). MacNeil (1978) asserted that in a relational exchange relationship, transactions 
transpire over time such that a transaction's history is viewed in order to promote anticipation into the future. Going by this standpoint, Ganesan (1994) asserted that communal or relational relationship has a long-term orientation. An organisation often engages in communal or relational exchange relationships with different stakeholders such as the community and their employees in order to add value to itself. Communal relationships with different stakeholders are important if an organisation wants to contribute to its community and to be socially responsible. Participants often derive personal satisfaction, which in most cases results in social exchange. This is because participants' duties occur over a period. Dwyer et al (1987, p. 13) differentiate discrete transaction relationships from relational exchange relationships using 12 key features of a contract, as shown in table1.

Table 1. A Comparison of Transaction and Relational Exchange Relationships (Adapted from Dwyer et al., 1987)

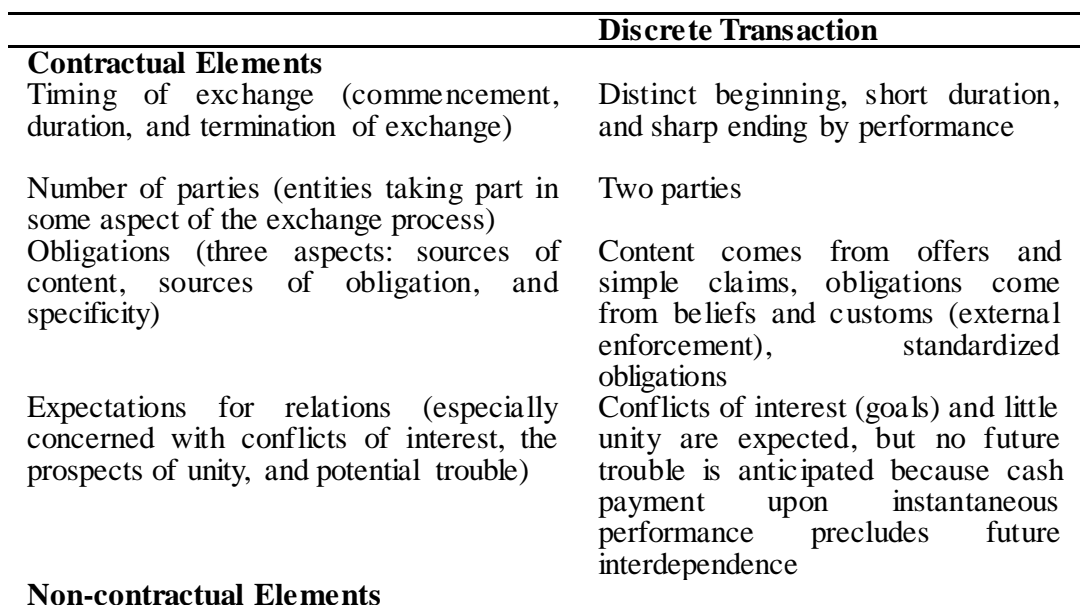

Relational Exchange

Primary personal relations (social Minimal personal relationships; interaction and communication)

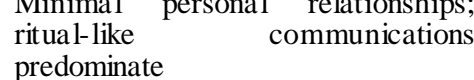

Contractual solidarity (regulation of Governed by social norms, rules, exchange behaviour to ensure etiquette, and prospects for self-gain performance)

Transferability (the ability to transfer rights, obligations, and satisfactions to other parties)

Cooperation (especially joint efforts at performance and planning)

Planning (the process and mechanisms for coping with change and conflicts)

Complete transferability; it matters not who fulfils contractual obligation

No joint efforts

Primary focus on the substance of exchange; no future is anticipated

Commencement traces to previous agreements; exchange is longer in duration, reflecting an ongoing process Often more than two parties involved in the process and governance of exchange Content and sources of obligations are promises made in the relation plus customs and laws; obligations are customized, detailed, and administered within the relation

Anticipated conflicts of interest and future trouble are counterbalanced by trust and efforts at unity

Important personal, noneconomic satisfactions derived; both formal and informal communications are used

Increased emphasis on legal and self-regulation; psychological satisfactions cause internal adjustments Limited transferability; exchange is heavily dependent on the identity of the parties

Joint efforts related to both performance and planning over time; adjustment over time is endemic

Significant focus on the process of exchange; detailed planning for the future exchange within new environments and to satisfy changing goals; tacit and explicit assumptions abound

Measurement and specificity (calculation and reckoning of exchange)

Little attention to measurement and specifications; performance is obvious

Significant attention to measuring, specifying, and quantifying all aspects of performance, including future benefits

Power (the ability to impose one's will on Power may be exercised when others)

promises are made until promises are executed

Division of benefits and burdens (the Sharp division of benefits and extent of sharing of benefits and burdens)

burdens into parcels; exclusive allocation to parties

Increased interdependence increases the importance of judicious application of power in the exchange

Likely to include some sharing of benefits and burdens and adjustments to both shared and parceled benefits and burdens over time

This is not to say that discrete transaction or exchange relationships should be discarded. Rather, researchers should recognise that often times, relationships begin with an exchange relationship and subsequently de velop into relational or communal relationships as time passes. Contrary to this, Grunig (2002) argued that organisations could need to start a relationship from a communal relationship in order to arrive at an exchange relationship. Nevertheless, Grunig (2002) asserted that an organisation's measure of relationship success with its various stakeholders will relate to its level of communal or relational relationship with such stakeholders. Ganesan (1994) concluded that long-term relationships place an organisation in a sustainable competitive position, promote cooperation, allow mutual dependency among parties involved, and encourage goal and risk sharing.

\subsection{Relationship Elements}

It is worth stating that there are limited research studies on relationship elements. Hence, the field has been 
dominated by a few researchers. Medlin et al (2005), Hakansson and Snehota (1995), and Hakansson, Blankenburg and Johanson (1992) demonstrated through a robust framework the properties of a relationship using network analysis, in which actors are seen to be performing activities and/or control resources. They suggest that relationships can only be meaningful when considered in respect of three elements i.e. actor bonds, activity links, and resource ties. Hakansson and Snehota (1995) stated that a partner relationship involves three crucial aspects of activity links, resource ties and actor bonds.

"Activity links embrace activities of a technical, administrative and marketing kind"

"Resource ties include exchanging and sharing resources which are both tangible, such as machines, and intangible, such as knowledge"

"Actor bonds are created by people who interact and exert influence on each other and form opinions about each other"

Halinen et al (1999) added that actor bonds, activity links and resource ties bind relationship partners' together, thus giving rise to interdependence and stability between them. Ford et al (1998) argued further that the presence of these properties in any relationship could result in either a transactional relationship, a facilitative relationship or an integrative relationship. Ford et al (2008) concluded that activity links, actor bonds, and resource ties are critical to relationship partners'strategy and capability development.

\subsection{Relationship Quality and its Context of Study}

Relationship quality as a concept results from research and theory in the field of relationship marketing (e.g. Dwyer et al. 1987; Crosby et al., 1990; Gronroos, 2000; Gummesson, 1987; Gummesson, 2000), wherein the main focus is to strengthen and make stronger existing relationships (Berry and Parasuraman, 1991). Crosby et al (1990), and Garbarino and Johnson (1999) stated that relationship quality provides an assessment of the strength of a relationship. These definitions suggest that relationship quality focuses on the assessment and evaluation of how well or satisfied relationship partners are in the fulfilment of their expectations or needs. Hakansson (1982) added that during the evaluation process of a relationship, it is imperative to take into consideration the relationship partners behaviour and their ability to meet one anothers needs, while Jap et al. (1999) contemplated that relationship quality assessment focuses on different aspects (e.g. future expectations, and process and attitudinal variables). The last-mentioned definition implies that relationships consist of various processes where by one process serves as a prerequisite to the other (Jap and Anderson, 2007; Dwyer et al. 1987) and that a relationship requires frequent assessment (Eggert et al. 2006). Johnson $(1999$, p. 6) ass erts that relationship quality is "the overall depth and climate of the inter-firm relationship", while Huntley (2006, p. 706) concluded that relationship quality is the "degree to which buyers are satisfied over time with the overall relationship".

In addition, some scholars provide a context-based relationship quality definition, which focuses on relationship parties' interactions. For example, Lagace et al (1991) define relationship quality as the level of interaction between relationship parties (i.e. the physician and the pharmaceutical sales person). In a different context, Moorman et al. (1992, p. 316) viewed relationship quality as "the degree to which users view user-researcher interactions as productive". Holmlund (2001, p. 15) provides a working definition that views relationship quality as "the joint cognitive evaluation of business interactions by key individuals in the dyad, comparatively with potential alternative interactions". These context-based definitions also suggest that relationship quality focuses on an evaluation of the relationship based on either relationship partners' interaction over a period (Boles et al. 1997; Holmlund, 2001) or the outcome of relationship partners' interaction (Moorman et. 1992). These definitions suggest that relationship parties are required to establish a working relationship which allows adequate and appropriate information and/or other resources sharing.

Furthermore, relationship quality has been defined in relation to the exchange of intangible rewards among relationship parties. For example, Levitt (1986, p. 302) referred to relationship quality as "a bundle of intangible value which augments products and results in an expected interchange between buyers and sellers". Likewise, Crosby et al (1990) asserted that relationship quality is a higher order construct composed of satisfaction and trust among relationship parties. Relationship quality from this standpoint connotes that a party to a relationship could receive its reward by gaining the trust and satisfaction of another party to the relationship. In addition, Bejou et al (1996, p. 137) defined relationship quality as when "the customer is able to rely on the salesperson's integrity and has confidence in the salesperson's future performance because the level of past performance has been consistently satisfactory". In this last definition, integrity and performance are regarded as intangible rewards. However, there is an element of time i.e. these rewards tend to materialise over time into the future. Crosby et al $(1990$, p. 76) concluded that "relationship quality contributes to a lasting bond by offering assurance that the salesperson will continue to meet the customer's expectations (satisfaction) and not knowingly distort information or otherwise 
subvert the customer's interests (trust)."

Also evidenced from research, (e.g. Crosby et al. 1990; Storbacka et al. 1994; Kumar et al. 1995; Bejou et al. 1996; Hennig-Thurau and Klee, 1997; Dorsch et al. 1998; Wulf et al. 2001; Walter et al. 2003; Lages et al., 2005) relationship quality has also been discussed within other fields outside of relationship marketing. Fynes et al (2005), within the supply chain discipline, define relationship quality as the extent to which parties in a relationship are involved in a long-term and active relationship. This is similar to Golicic and Mentzer's (2005) definition of relationship quality as the strength or degree of closeness of relationship parties within a relationship. It is obvious that relationship quality is an important feature in de veloping a successful relationship (Rauyruen and Miller 2007; Palmatier et al. 2006; Woo and Ennew 2004). Hence, relationship quality has become a key aspect within the relationship marketing discipline (Smith, 1998a; Hennig-Thurau et al., 2001; Gummesson, 2002).

Building on the foregoing, it is clear that relationship quality as a concept lacks a common definition (Sheth and Parvatiyar, 2002; Palmatier et al. 2006). However, Dwyer and Oh (1987), Dorsch et al (1998), Crosby et al (1990), Robert et al. (2003), and Woo and Ennew (2004) concluded that relationship quality is usually defined as a higher-order construct consisting of several distinct but related components. Evidence suggests that relationship quality has been studied, developed and empirically tested within the confine of different research contexts (Wong et al., 2005; Vieira et al, 2008). These research contexts range from interpersonal relationships (i.e. relationship between individuals), business-to-business relationships (B2B), business-to-customer relationships (B2C), and customer to business relationships (C2B).

Interpersonal relationship is the relationship between two or more individuals, customers, or consumers, such as the relationship between a couple i.e. husband and wife (Zimmerman and Robert, 2012). Also, the relationship between different customers through online auctions such as Amazon, eBay and Gumtree can be classified under this relationship type.

A B2B relationship is perceived as a working relationship between two or more firms (Dwyer et al., 1987, Anderson and Narus, 1990; Ganesan, 1994; Chumpitaz and Paparoidamis, 2007). It also involves one business making a commercial deal or transaction with another (Gummesson, 2004). For example, manufacturers in business markets relationship with their suppliers (Johnson and Selnes, 2004; Ulaga and Eggert, 2006), and an automobile manufacturer's relationship with a dealer (Dwyer et al., 1987).

A B2C relationship describes the relationship between a business and its final consumer. For example, an automobile retailer and its customers (Morgan and Hunt, 1994), a financial institution and its customers (Zineldin, 1995; Bejou et al 1996; Lang and Colgate, 2003; Rauyruen and Miller, 2007), and a hotel and its guests (Bowen and Shoemaker, 1998).

A C2B relationship describes the relationship between an indi vidual customer and a business entity (Law et al., 2003). This is the reverse to the B2C relationship model. For example, the relationship between a patient and his/her surgery (Griswold, 2003), and an indi vidual (i.e. customer or consumer) making an online call to a call centre (Wong et al., 2005).

\subsection{Relationship Quality Constructs}

Despite the growing body of literature on relationship quality constructs, scholars have argued that there exists a high level of uncertainty as to which of the relationship quality constructs can be categorised as determinant or dimension (Vieira et al., 2008; Rauyruen and Miller, 2007; Ivens and Pardo, 2007; Huntley, 2006). However, a review of relevant literature suggests that trust, satisfaction and commitment are the main constructs of relationship quality (Moorman et al., 1992; Dwyer and Oh, 1987). This has streamlined the focus of the majority of the empirical research conducted on relationship quality to trust, satisfaction and commitment, thus giving little or no attention to a large number of other constructs (Dwyer et al., 1987; Anderson and Narus, 1990; Morgan and Hunt, 1994; Ulaga and Eggert 2006; Carr, 2006; Ndubisi, 2006; Hsin Hsin and Po Wen, 2009; Barry and Doney, 2011; Rafiq, Fulford and Lu, 2013). Relationship quality is usually defined as a higher-order construct consisting of several distinct but related components (Dorsch et al. 1998; Smith, 1998a; Van Bruggen et al. 2005; Ulaga and Eggert 2006; Rauyruen and Miller, 2007). These constructs are also referred to as components, which are categorised either as determinants of relationship quality or dimensions of relations hip quality (Athanasopoulou, 2009). This is because there is no consensus among scholars as to the constructs of relationship quality. See Appendix A for a detailed and comprehensive list of various relationship quality constructs.

\subsubsection{Determinants of Relationship Quality}

The lack of agreement as to the constructs that make up the determinants of relationship quality could be linked to the context, perspective and research settings in which various studies have been carried out (Vieira et al., 2008). 
Determinants of relationship quality are referred to as precursors of relationship quality (Vieira et al., 2008). Table 2 lists authors who have cited mutual benefit, communication and control mutuality as the most frequently used constructs functioning as determinants of relationship quality.

Table 2. Determinants of Relationship Quality (summarised from the literature)

\begin{tabular}{ll}
\hline CONSTRUCT & AUTHORS \\
\hline Mutual benefit & Huntley, 2006; Parson, 2002; Vieira, 2001; Boles et al., 2000; \\
& Smith, 1998a; Lagace et al., 1991; Crosby et al., 1990 \\
\hline Communication & Ndubisi, 2006; Athanasopoulou, 2006; Bennett and \\
& Barkensjo, 2005; Sanzo et al., 2003; de Ruyeter et al., 2001; \\
& Vieira, 2001; Goodman and Dion, 2001; Selnes, 1998; Smith, \\
& 1998b; Leuthesser, 1997; Menon et al., 1996; Kumar et al., \\
& 1995; Morgan and Hunt, 1994 \\
\hline Control mutuality & Kent and Taylor, 2002; Hon and Grunig, 1999; Stafford and \\
\hline 3.4.2 Dimensions of Relationship Quality & Canary, 1991; Rusbult, 1983
\end{tabular}

The constructs that make up the dimension of relationship quality are not clearly distinguished or defined from one another. However, the main dimensions of relationship quality consistently identified and evaluated in the literature are trust, satisfaction and commitment (Vieira et al., 2008; Athanasopoulou, 2009). Hence, the focus of this study will be on trust, satisfaction and commitment, which are the most mentioned and studied constructs within the literature. These three constructs are also referred to as measures of relationship quality (Athanasopoulou, 2009). Other scholars (e.g. Kempeners, 1995; Crosby et al., 1990) referred to trust, satisfaction and commitment as the key relationship management building blocks. In addition, these three constructs were selected because they have been validated in different contexts and they form an area of convergence for otherwise differentiated studies on dimensions of relationship quality. Dorsch et al (1998), Smith (1998a), Hennig-Thurau et al (2002), Robert et al. (2003), Ulaga and Eggert (2006), and Rauyruen and Miller (2007) referred to the three constructs as essential indicators of good relationship quality. Arguably, the three dimensions of relationship quality (i.e. trust, satisfaction and commitment) are not independent. Hence, there is a casual link between the dimensions of relationship quality (Hennig-Thurau and Klee, 1997).

\section{The Study Theoretical Framework}

Based on the review of previous literature which gives an insight into the main elements, determinants and dimensions of relationship quality, figure 1 present the proposed research study framework.

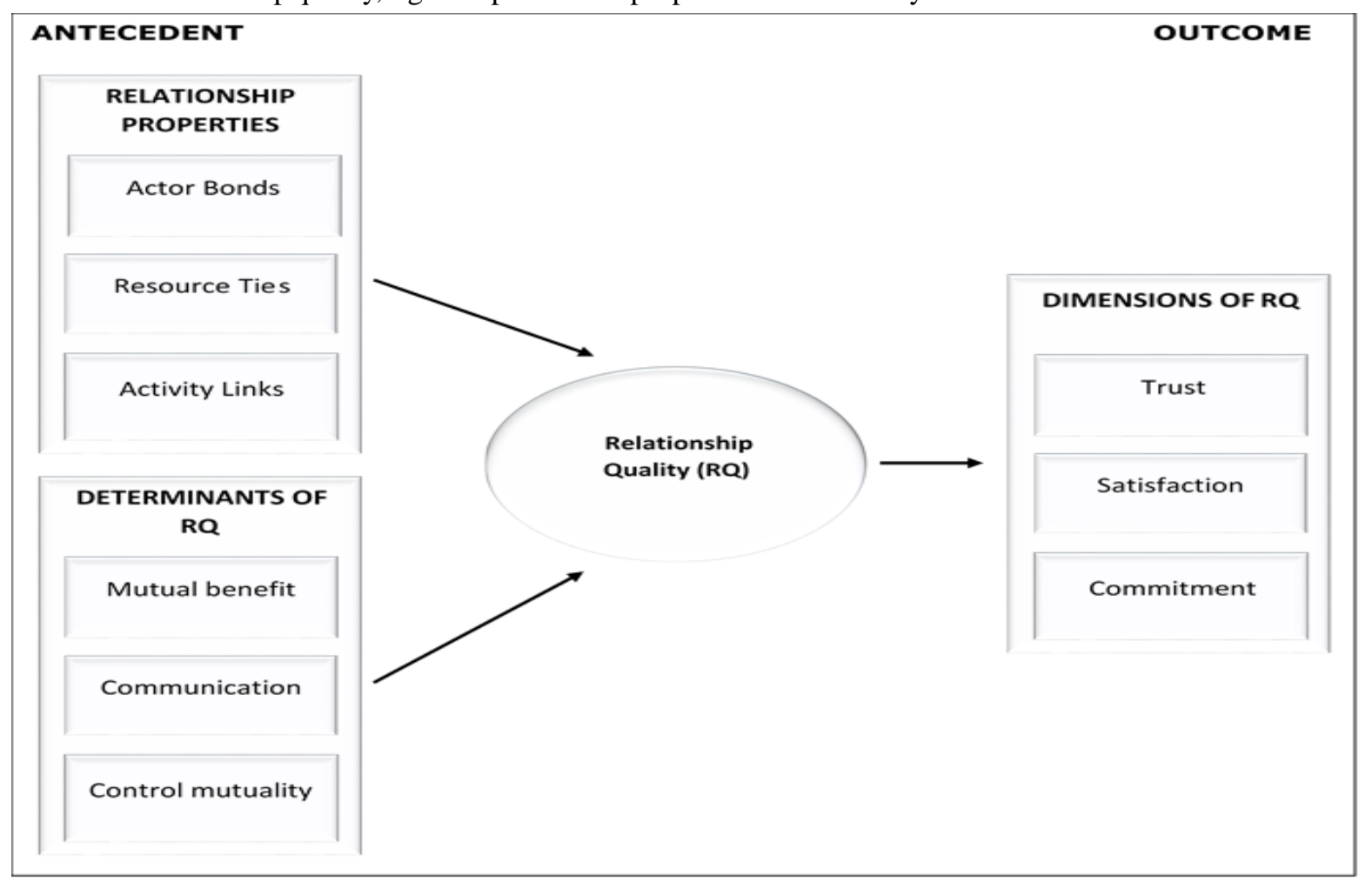

Figure 1. Research Study Theoretical Framework for a B2Com Relationship Quality (author generated) 


\section{Methodology}

This research study aims to explore and understand the relationship elements and relationship quality constructs that are important in establishing a mutually beneficial relationship between a business and the community in which it operates. This was approached from the perspective of the community. Therefore, an exploratory research study was taken on board in order to gather the views and opinions of the host community. This is because the various relationship elements and relationship quality constructs identified by researchers and scholars (in a different context), which serve as the basis for this research study require a better understanding within a B2Com context. The process involved in carrying out this research is:

1. Defining the research study aims, which are to explore and understand the nature and quality of the relationship between the OPC and $\mathrm{HC}$ by considering the relationship elements, determinants of relationship quality, and dimensions of relationship quality as the basis of establishing and de veloping a successful relationship quality between the OPC and $\mathrm{HC}$, and to develop a framework capable of assessing a B2Com relationship.

2. Formulating research objectives for the study. These are; to examine the nature and quality of the relationship between the OPC and HC in the NDRN, identify the relationship elements and key determinants and dimensions of relationship quality which the OPC could use to build and sustain a mutual sense-making relationship, and determine the impact of current relationship quality frameworks in improving and enhancing the integration of OPC and HC in the NDRN.

3. A detailed and comprehensive literature review was carried out in order to ascertain the research problem. In addition, the key relationship determinants and relationship dimensions suggested by scholars and researchers based on different research contexts were identified. This informed the development of the current study's theoretical framework as shown in figure 1.

4. Subsequently, data were collected from sixteen research participants from three states using an in-depth semi-structured interview, which is 'the verbal interaction between one or more researchers and one or more respondents for the purpose of collecting valid and reliable data to answer particular research questions" Parahoo (2006, p. 307). The semi-structured interview was designed to give room for flexibility, which Bryman and Bell (2004) considered important because it allows the interviewer the opportunity to vary the interview questions and probe any inconsistent interviewee's response. The interview schedule focused mainly on exploring:

The key elements of a relationship: The purpose of this is to gain a detailed insight and background into the nature of the relationship between the OPC and HC from the HC point of view. In addition, it gave the research participants the opportunity to themselves assess and evaluate the relationship between the OPC and HC

The determinants of relationship quality: This focuses on capturing and understanding the constructs that give rise to relationship quality. In addition, why research participants consider such constructs as essential in achieving effective relationship quality. Crosby et al (1990) referred to these constructs as the antecedents of relationship quality

The dimensions of relationship quality: This aspect is included in order to establish and explore the likely constructs which serve as indicators of the level or state of the quality of relationship. Hence, it measures the quality of relationship between the OPC and HC. The interview questions explored under this section focus on relationship quality evaluation.

However, prior to carrying out interview sessions with different research participants, a pilot study was carried out in order to identify and correct the deficiencies and lapses in the research design procedure prior to major or main studies (Aitman et al., 2006). Polit and Beck (2009) defined a pilot study as a trial or small-scale version conducted prior to a major study. Arguably, a pilot study could be seen as a means of avoiding resource waste i.e. money or time. This was carried out via the telephone with five experts and operators in the field within the current context of study. Hence, the researcher was able to test the initial research interview questions and, from responses received, develop the final research interview questions (McNamara, 1999). Furthermore, the outcome of the pilot study informed the current study sample selection, which was based on selective sampling. Selective sampling originates from restrictions placed upon the researcher's observations by the research settings and/or context. Sandelowski et al (1992, p. 302) referred to selective sampling as "a decision made prior to beginning a study to sample subjects according to a preconceived, but reasonable initial set of criteria. Likewise, Glaser (1978, p. 37) defined selective sampling as "the calculated decision to sample a specific locale according to a preconceived but reasonable initial set of dimensions (such as time, space, identity or power) which are worked out in advance for a study". This 
suggests that the ability of the researcher to select the appropriate sampling method depends on his or her understanding of the research context and/or settings. Coyne (1997) termed selective sampling as a purposeful sampling. Patton (2002) added that this sampling technique is widely used in qualitative research studies in order to identify and select information-rich research participants, while Cresswell and Plano Clark (2011) concluded that selective sampling involves identifying and selecting individuals that have experience or knowledge about a phenomenon of interest. Within the NDRN are nine independent states (i.e. Abia, Akwa Ibom, Bayelsa, Cross River, Delta, Edo, Imo, Ondo and Rivers). However, three of these states (i.e. Bayelsa, Delta and Rivers) were selected for the purpose of data collection because they are worst affected due to the intensity and nature of oil production and operations, which are mostly onshore. In addition, these states experience the highest level of violence and conflicts compared to the remaining six other states in the NDRN.

The data collected was analysed using content analysis. This method of data analysis has been used both by quantitative and qualitative scholars. For example, Kaplan (1943, p. 230) referred to it as "a technique which attempts to characterise the meaning in a given body of discourse in a systematic and quantitative fashion". Likewise, among the qualitative scholars, Hsieh and Shannon (2005, p. 1278) define content analysis as a "research method for the subjective interpretation of the content of text data through the systematic classification process of coding and identifying themes or patterns". Webber (1990) argued that content analysis as a method of data analysis focuses directly on the transcript and/or text of human communications because communication is core to social interaction. Franzosi (2004) added that content analysis is often used to capture the key themes that emerge from a transcript and/or text.

Harris (2001) asserted that content analysis is important for studying organisations, beliefs, human relations and attitudes. Therefore, content analysis could be considered the most appropriate approach for the purpose of analysing data collected through interviews in order to understand and explore people's views and opinions on the quality of a relationship (Golicic and Mentzer, 2005). Hence, it offered the researcher the opportunity to test and utilise the theoretical framework developed in order to assess and understand the quality of relationship between the OPC and HC. To this end, this research study adopted Harris's (2001) eight step process for the purpose of data analysis as shown below:

1. Identify the questions to be asked and constructs to be used.

2. Choose the texts to be examined.

3. Specify the unit of analysis.

4. Determine the categories, or themes of meaning. Into which responses are divided.

5. Generate a coding scheme or coding rules.

6. Conduct a sample or pilot study.

7. Collect the data and revise the scheme as necessary.

8. Analyse the data and assess validity and reliability.

\section{Results and Discussion}

\subsection{Antecedents of Relationship Quality}

Data analysis revealed that activity links, actor bonds, resources ties, mutual benefit, communication, control mutuality, culture and mutual goal are perceived as antecedents of relationship quality.

\subsubsection{Activity Links}

Activity links become important when building a relationship because the parties involved are linked to each other through their various activities, and these links capture the efficiency in the use of resources. Hakansson and Snehota (1995) described activity links as a flow of exchange episodes involving each party to a relationship undertaking one or more activities. This description suggests the need for involvement and coordination between relationship partners as they will consequently affect how activities are carried out in the rel ationship. Interviewees' understanding of activity links in this study reflects the act of participation in something, association with someone or a situation, engrossment with something which relies on performance, being considered as a necessary part of something, and when your contribution counts. These are consistent with Hallen et al (1989), Turnbull and Valla (1986) and Hakansson's (1982) finding that relationship partners in any relationship are linked through activities.

Data gathered suggested that activity links are an important starting point when building a B2Com relationship. Whilst it is considered as a means by which a business and its community are brought together, the majority of the interviewees asserted that activity links increase the level of awareness and involvement between relationship 
partners. Whilst some argued that activity links bring about proper engagement and a "right" connection, others added that proper interaction, exposure to opportunities and community building will result when there is appropriate activity links between a business and its community. Thus, the activity links in a relationship have dynamic (de velopments) and structural (efficiency) effects (Hakansson and Snehota 1995) and also lead to the development of capabilities (Teece et al 1997). Moller and Torronen (2003) stated that activity links affect interaction in any relationship. Research participants argued that activity links de velop when the activities of parties to a relationship are understandable and visible to one another. They concluded that activity links is inherent in achieving trust between the relationship partners in a B2Com relationship.

\subsubsection{Resources Ties}

Resource ties capture a party's awareness and knowledge about the resources of another party within a relationship (Holmen et al 2005). Resource ties develop as parties in a relationship access or exchange resources with one another as they carry out their respective activities. In most cases, the development process transforms existing resources of the parties so as to create new resources. This further suggests that relationship parties interact and become aware of one another's resources. Hence, as resource ties develop between two parties in a relationship they become mutually and increasingly interdependent (Hakansson and Snehota 1995).

As with activity links, research participants perceived resource ties as a key component in this relationship context. They argued that resource ties will facilitate exchanges and create positive connections between relationship partners. The findings suggested that resource ties occur when partners become aware of, and interact about, their respective resources. Research participants argued further that the resources that bring together both a business and the community in which it operate must be mutually shared between the two parties. Hence, there will be efficient use and de velopment of relationship resources (Kalwani and Narayandas, 1995; Turnbull et al., 1996; Wilkinson, 1998; Spencer et al., 2003). Arguably, it is evident from the data collected and analysed that the existence of resource ties is an essential relationship element that should be taken into consideration as being of benefit for the relationship parties. Hence, research participants concluded that resource ties between relationship partners is important to achieving trust.

\subsubsection{Actor Bonds}

Similar to resource ties, actor bonds refer to the ways that parties in a relationship respond to and perceive each other. Actor bonds impact on the identities of relationship partners towards one another and also affect the way these partners view and interpret situations. Hakansson and Snehota (1995, p. 198) stated that "identities, to begin with diffused, are shaped by the mutual interaction and its interpretation by the individuals within the two parties over time". Hence, parties in a relationship react to one another's actions in diverse situations. The de velopment of identities between two parties in a relationship is largely related to developing commitment and trust. Hakansson and Snehota (1995) argued that commitment connotes to what parties will do for one another i.e. realizing of potential, while trust relates to what parties can do for one another i.e. identifying of potential. Hence, actor bonds between partners in a relationship emerge over time and are mutually developed through the experience and knowledge gained via interaction.

Research participants acknowledged the need for actor bonds to be mutually developed between relationship partners. They argued that this should take into consideration the long-term needs of the relationship partners. Hence, it will create a source of relationship bonding between them. Furthermore, research participants asserted that the presence of bond between relationship partners encourages frequent communication, which they perceived as a means of creating harmony and avoiding conflict in such relationship. This view by the research participants is consistent with Hakansson and Snehota's (1995) that appropriate actor bonds between relationship partners will result in proper communication and efficient use of their respective capacity. Likewise, they argued that bond between relationship partners encourages and influences their level of commitment. This is bec ause relationship partners tend to show more commitment in maintaining a relationship when they have a strong personal relationship. In addition, the research participants acknowledged that appropriate bonds between relationship partners will result in satisfaction, which facilitate efficient use of their respective capacity within the relationship. They concluded that bonding between relationship partners will give rise to trust, which encourages openness between the parties.

\subsubsection{Mutual Benefit}

Data gathered revealed that for mutual benefit to exist between a business and the community in which it operate, there must be cooperation between them. Research participants acknowledged that a lack of agreed mutual benefit between the OPC and $\mathrm{HC}$ has resulted in underutilisation of resources within the region, leading to an increase in waste. This conforms to Wilkinson and Young's (2002) argument that cooperation is a form of resource acquisition 
strategy, while competition is a strategy useful in attaining marketplace advantage. Even though, from the business perspective, the OPCs are used to competition than cooperation. Furthermore, findings from the data gathered revealed that mutually agreed benefit between partners' prompts commitment. This is consistent with Morris et al (2007) and Morgan \& Hunt's (1994) claim that mutual benefit influences commitment within a relationship. This suggests that the community in which a business is located (i.e. carry out its operations) will show commitment to the relationship with such a business if the community perceives greater benefit from the presence of the business. Similarly, data gathered revealed that trust has a positive impact on mutual benefit, which invariably results in relationship success. This is congruent with Zabkar \& Brencic's (2004) assertion that trust between partners is a means of shaping partners' intentions and behaviours. Research participants concluded that the earlier both a business and its community consider one another as cooperating partners, by ensuring mutuality of benefits accruable to one another, the sooner they will both enjoy a smooth and peaceful relationship. Morris et al (2007) corroborate that the lesser the competitive rivalry between partners, the higher will be the opportunity for a mutually beneficial relationship. These findings emphasise the importance of a business and its community ensuring mutuality of benefit between one another; benefits associated with information and resources particularly help in achieving a successful relationship.

\subsubsection{Communication}

Communication was interpreted as being an important factor that gives rise to trust, which is essential in building commitment to the relationship enhancement management between a business and its community. For effective and efficient communication purposes, most research participants emphasized the importance of employing a communication strategy that considers the nature of the information to $b$ shared, and the affected entity within the community, in order to determine how such information will be transmitted. It was suggested by interviewees that a direct and face-to-face communication between the OPC and community people would be ideal. By doing this, research participants argued that a business would have access to first-hand information, and access to immediate feedback from the community (Cannon and Homburg, 2001).

Highlighting the importance of communication between a business and its community within the NDRN context, data gathered clearly showed that communication is crucial in maintaining continuity between the two parties because this would produce the intended or desired result within the relationship, while inadequate communication will often result in conflict and violence. In addition, research participants argued that untimely sharing of information would negatively impact the quality of relationship between relationship partners. Hence, relationship parties must be proactive in their communication process in order to arrive at the desired result. Furthermore, research participants established a connection between communication and trust. Afew of the interviewees argued that trust is an afterward effect of effective communication. Their views show that effective communication has both direct and indirect outcomes in upholding trust between a business and its community within the relationship. These views support Anderson et al's (1987) assertion that communication is positively related with trust. This implies that effective communication will play an important role in maintaining, upholding and strengthen the level of trust between relationship partners in a B2Com relationship. Hence, communication has significant impact on trust.

Furthermore, communication flow was perceived as a strong predictor of satisfaction between relationship partners by interviewees. This is because proper and adequate communication between relationship partners increases their satisfaction level. A majority of the research participants concluded that communication is a prerequisite for commitment, while others perceived communication as a determinant of commitment.

\subsubsection{Control Mutuality}

In general, research participants perceived control mutuality as the power balance in a relationship. This they referred to by agreeing with the distribution of power and level of mutual influence between relationship partners. This is in line with Men (2011) and Hon \& Grunig's (1999) assertion that control mutuality shares some similarity with empowerment and a feeling of control because it is relevant to power sharing and influence. Data gathered revealed that the more a community can influence and/or control matters and issues pertaining to their relationship with a business entity, the more strongly such community believes that the business values the community's ideas and opinions. This suggests that a commendable level of interactivity and interaction between a business and its community will be of significant importance. Research participants argued that the lack of power balance between relationship partners will always result in violence and conflict. This is consistent with Stafford \& Canary's (1991) claim that satisfaction with and/or agreement on the way things are done, or decisions are made, in a relationship signifies control mutuality. This further suggests the importance of relationship parties actively incorporating conflict management ability and effective communication in their relationship. 
Furthermore, control mutuality was expressed in relation to decision-making between relationship partners. Research participants argued that a relationship lacks stability and interdependence when decisions that originate from such a relationship do not reflect each party's opinion. In addition, it was revealed that two-way communication between a business and its community in their decision making process is pertinent in attaining a control mutuality position. Research participants asserted that a business must allow the self-efficacy (e.g., enhance their control ability and empower them) of the community in which it operates in order to gain their satisfaction. These findings suggest that there is a need for appropriate power-sharing between relationship parties.

\subsubsection{Culture}

Culture is one of the themes that emerged during the data analysis process. A majority of the research participants stressed the need for a business to understand the cultural heritage of the community in which its operations are being carried out in order to obtain a productive and successful relationship with such a community. In addition, the research participants added that the various strategies employed by a business must take into cognisance the importance of the people's cultural heritage in order to avoid violence and conflicts. This finding is in line with Tobor and Muzorewa (2016, p. 15) assertion that "A majority of researchers writing on the Niger Delta crisis proffered possible solutions without considering the significance of the culture of the people for whom the program is meant". Even though there is no consensus on the definition of "culture", it is usually perceived to connote values and beliefs. Jaques (1951) defined culture as a traditional and customary way of thinking and doing things, shared by all its members. This suggests that members are bound by a common set of values and that any new member must learn and at least partially abide by such values in order to be accepted. Research participants concluded that culture plays a significant role on how a community engages with the outside world, such as business coming into their community, and that it is embedded in community participation (Tobor and Muzorewa, 2016). Hence, involving the community in a B2Com relationship context could lead to increased quality of decisions, access to new information, and enhanced fairness.

\subsubsection{Mutual Goal}

Wilson (1995) defined mutual goals as the extent to which relationship partners share goals which are meant to be achieved jointly by the relationship partners, and the maintenance of such a relationship. Hence, parties to a relationship must all participate in the relationship as agreed (Adler, 1967). McQuiston, (2001) added that mutual goals provide relationship partners with the right conditions and the opportunity to participate effectively in a relationship. Vieira et al (2008) argue further that mutual goals between relationship partners encourages similarity of values, such that relationship partners equally work towards a common long-term goal or achievement. Zineldin (2004) stated that a mutual goal is when relationship parties cooperate and coordinate their activities together. These definitions further suggest that relationship parties are expected to work towards achieving a unified goal that could create value and mutually beneficial exchanges.

The research participants emphasised the benefit of involving the community in the formulation of goals and strategies that affect the communities. They stated that the OPC relationship with the HC will be successful when the OPC takes into cognisance the community when making decisions and formulating strategies. This is consistent with Zineldin's (1998) standpoint that a mutual goal is a way of integrating a relationship such that partners' will achieve a common goal. Vieira et al (2008) argued that the nature of a mutual goal should be considered as a core determinant of relationship quality. Likewise, some scholars (e.g. Huntley, 2006; Parsons, 2002; Boles et al., 2000; Smith, 1998a; Lagace et al., 1991; Crosby et al., 1990) asserted that mutual goal is one of the most commonly emphasised relationship quality determinants. The research participants stated that when both the OPC and $\mathrm{HC}$ pursue the same goal(s), their level of trust and satisfaction would improve. These excerpts are in line with Anderson and Weitz's (2008) assertion that trust between relationship partners is enhanced when they share similar goals, and Vieira et al's (2008) argument that the level of satisfaction experienced by parties to a relationship is enhanced when they share mutual goals. Likewise, the research participants argued that when both the OPC and HC share a mutual goal, there level of commitment will improve. Hence, this research study considers mutual goal as a determinant of relationship quality.

\subsection{Relationship Quality Outcome}

Data analysis revealed that trust, satisfaction and commitment are termed as the relationship quality outcome.

\subsubsection{Trust}

Within the literature, trust has been viewed from two distinct standpoints (LaBahn and Kohli, 1997). One standpoint viewed trust as a combination of behavioural intentions and beliefs (Moorman et al 1992), while the other considered trust to centre on trustworthiness (Morgan and Hunt 1994, Anderson and Weitz 1989). This study 
adopted Morgan and Hunt's (1994) standpoint which referred to trust as trustworthiness. In addition, trust has been studied at three different levels; firstly, at the individual level (Crosby et al 1990), secondly at the organisational level (Garbarino and Johnson 1999), and thirdly Rauyruen and Miller (2007), and Karantinou and Hogg (2009) focused on both individual and organisational level. Regardless of these views and levels of study, Smyth et al (2010) concluded that trust is not a calculated judgement but rather an attitude which is socially measured through interactions.

It was made known that trust is developed over time through numerous interactions and information sharing between relationship partners. Hence, communication is an important driving factor for relationship parties to act to establish trust. Research participants revealed that a business's perceived honesty, openness and reliability in giving appropriate and timely information on issues that affect the $\mathrm{HC}$ is crucial to the success of a B2Com relationship. This will help the parties build mutual understanding and establish confidence between them and also reduces the risks associated with failed projects and over-promising. Research participants noted that trust has a positive impact on satisfaction. They argued that when relationship partners share a higher le vel of trust, they would be less concerned or worried about their level of interaction, which ultimately results in a greater level of satisfaction with each other. In addition, research participants added that trust between a business and its community is important in establishing commitment between the OPCs and the HC. They concluded that commitment will be the follow-on effect of a business and its community improving the level of trust between them.

\subsubsection{Satisfaction}

Satisfaction is the pleasurable fulfilment of need (Oliver 1997, 1999) and can be regarded as an overall evaluation of performance (Fornell 1992). Satisfaction from these two researchers' perspectives can be seen as an emotion-based judgement and an evaluation of a service experience. Oliver (2010) revealed that satisfaction can be judged and evaluated at three different stages; (i) during interactions, (ii) at the end of a series of interactions, and (iii) a global assessment taking into consideration the whole encounter and experience between partners.

The majority of the research participants argued that satisfaction is an essential construct because relationship parties must have a feeling of fair treatment. They stated that both the business and its community should be responsible for building and/or enhancing the level of satisfaction within a B2Com relationship. This suggests the need for a business and its community to have a common understanding of what constitutes satisfaction within their relationship context. Research participants added that satisfaction is perceived when desired outcomes are achieved, when agreed promises are fulfilled or when results are consented to by parties to the relationship. They concluded that when relationship partners are satisfied with their dealings and interactions with one another, they create an atmosphere that get each other committed to the relationship.

\subsubsection{Commitment}

Commitment, according to Caceres and Paparoidamis (2007), focuses on involvement, while La (2005) argued that commitment has two dimensions; relationship orientation and attitudinal disposition. Commitment for the purpose of this study has been termed as the desire of parties in a relationship to retain and maintain the relationship. This is consistent with assertions by Moorman et al (1992) and Anderson and Weitz (1992). Research participants argued that genuine commitment of relationship partners to each other results in a long-term and stable relationship. This is consistent with Gundlach et al's (1995) assertion that two-way approaches to commitment between partners promotes their relationship and fosters trust also. Research participants added that commitment presents relationship partners with an opportunity to determine their future exchanges and de velop a shared norm in the process.

\section{Contribution}

The success of existing research studies on relationship quality is shifting towards the study of new relationship types (Athanasopoulou, 2009). The concept of "relationship" is one that includes relationship parties who are not necessarily an organisation or individuals (Huang and Chiu, 200), or where the parties involved do not take on the traditional roles of a seller and buyer (Athanasopoulou, 2009). Osobajo and Moore (2016), and Athanasopoulou (2009) recommend that researchers should look at new relationship types between parties that may not be organisations or individuals using qualitative approaches to analyse the quality of relationship, while Vieira et al (2008) suggest that relationship quality constructs could be varied depending on the research context. Consequently, this research study extended the concept of relationship and relationship quality in several aspects.

First, this research study was the first of its kind to develop a detailed and comprehensive framework of relationship quality in the context of a business-to-community (B2Com) relationship in a unique commercial 
context. It draws from the literature in four main areas: interpersonal relationships (i.e. relationship between individuals), business-to-business relationships (B2B), business-to-customer relationships (B2C), and customer-to-business relationships $(\mathrm{C} 2 \mathrm{~B})$. Figure 2 demonstrate the final proposed model for a B2Com relationship model.

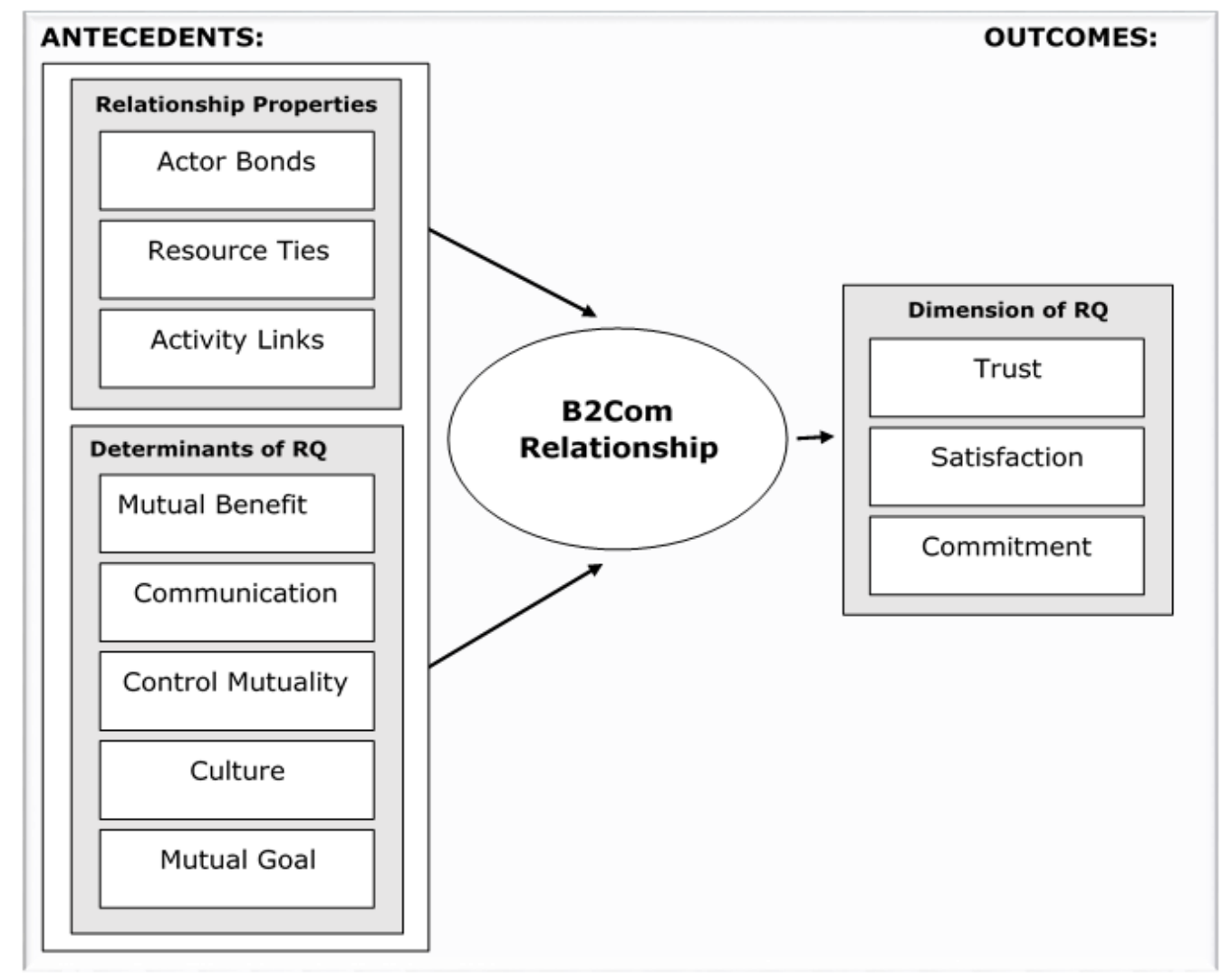

Figure 2. The Final Proposed Theoretical Framework for a B2Com Relationship Quality (author generated)

Second, existing research on the constructs of relationship quality have either analysed data deductively (i.e. by applying existing theories and literature to a specific research context (Hennink et al., 2010)) or inductively (i.e. moving from data to the development of framework (Kerlinger, 1986)) using a statistical or mathematical analytical tool (Osobajo and Moore, 2016). This is the first to employ both the deductive and inductive reasoning approaches using content analysis to inform the research final framework. This is because the two reasoning approaches to research give a detailed and comprehensive understanding of the concept of relationship quality within the context of a business-to-community relationship. Hence, certain determinants of relationship quality (i.e. culture and mutual goal) were identified by research participants (Vieira et al., 2008).

Third, this research study extended the application of relationship quality frameworks that were conducted in a developed economic environment such as the United Kingdom and United States of America (Osobajo and Moore, 2016) to a developing economic environment such as Nigeria through the replication of these frameworks. This is consistent with Vieira et al's (2008) suggestion that additional constructs may need to be included in order to acknowledge the context of the current study. Likewise, Collins (1985) stated that replication of previous or existing studies is imperative for the generation of knowledge, while Hubbard and Armstrong (1994) concluded that replication is the key to generalisation for the advancement of science. Even though researchers have made adequate and robust effort in developing these frameworks, the fact that these studies were carried out in a developed economy suggests scope for further replication and extension studies. In addition to mutual benefit, communication and control mutuality, this research study adds to the body of knowledge by confirming that culture and mutual goal are important determinants of relationship quality within the NOGI context.

Fourth, this research study also enhances the understanding of practitioners (i.e. public relation officers) working within the Nigerian oil and gas industry (NOGI) and other sectors on how to develop and maintain their relationship with the communities they operate within. It is obvious that as the OPCs experience difficulty in the exploration and production of crude oil, establishing and maintaining a mutually beneficial relationship will become more of a priority. In addition, the OPCs will be able to exploit crude oil resources that were previously 
uneconomical due to the accessibility of such resources. Practitioners need to work with the community to develop a mutually beneficial relationship that meets the needs of all relational parties. Effort should be made in creating a mutual goal atmosphere and understanding the culture of the people in order to develop a better relationship with the community.

\section{Limitations and Direction for Future Research}

Deciding on the research design for this research study resulted in certain trade-offs, which could limit the research findings.

The aim of this research study is to develop a framework that is capable of enhancing the quality of relationship between the OPC and HC, but with specific focus on the NOGI. In doing so, this research study offers a framework that draws from the literature reviewed and the data gathered. The research study analysis supported the connection and interlink that exists between the determinants of relationship quality and dimensions of relationship quality based on the samples surveyed. However, caution should be taken in generalising the rese arch study results to other sectors within the NDRN. This research study acknowledged that it is likely impossible to develop a framework that is appropriate for all sectors because of the following reasons:

1. The process followed in drawing the sample size for the research study produced results that were specific to the oil and gas industry. This is because research participants interviewed were selected based on their perceived knowledge of the relationship between OPC and HC within the NDRN, which may not be applicable to other sectors.

2. The use of content analysis as the most appropriate method for analysing the data collected through interviews in order to understand and explore people's views and opinions on the quality of relationship may not be applicable to other sectors.

Hence, further refinement and modification of the constructs proposed by this research study may be necessary in order to take into account the industry specific context of future research studies. Future research studies should consider using other sampling approaches such as a stratified systematic sampling which would divide the community population into the various groups, and each group of actor sampled using a systematic approach in order to obtain a reliable sample size.

Furthermore, this research study supported the relevance of the various relationship quality constructs suggested by previous scholars as used in this research study framework, and expanded the constructs to include culture and mutual goal. Howe ver, further research could explore the propositions formulated by the current study. In addition, future research studies should consider drawing samples from either the OPC or both the OPC and HC in order to have diverse opinions and views from research participants and facilitate investigation of the interdependence of the relationship. This is because the research samples selected for this research study come from the community only. It would be worthwhile if future research in the field of study could look into the optimum order in which the different constructs and/or elements identified within the framework would be effective in enhancing and/or improving a B2Com relationship. However, the order suggested by the findings of this research study flow from the interrelationships between the various elements and constructs that made up the study framework. Also, the findings suggested a linear relationship between trust, satisfaction and commitment. Having considered different relationship quality frameworks, this research study is concluded with the notion that the developed theoretical framework is a tool capable of enhancing and/or improving the quality of relationship between two or more relationship parties

\section{References}

Adelabu, N. S. (2012). The political economy of oil deregulation in Nigeria's fourth republic: Prospects and challenges. Journal of Emerging Trends in Educational Research and Policy Studies, 3(3), 193.

Adenugba, A. A., \& Dipo, S. O. (2013). Non-oil exports in the economic growth of Nigeria: A study of agricultural and mineral resources. Journal of Educational and Social Research, 3(2), 403. https://doi.org/10.5901/jesr.2013.v3n2p403

Adler, L. (1967). Resource pooling for mutual benefit. Management Review, 56(2), 59-64.

Aghedo, I. (2013). Winning the war, losing the peace: Amnesty and the challenges of post-conflict peace-building in the Niger delta, Nigeria. Journal of Asian and African Studies, 48(3), 267-280. https://doi.org/10.1177/0021909612453987

Aghedo, I., \& Osumah, O. (2014). Insurgency in Nigeria: A comparative study of Niger delta and boko haram uprisings. Journal of Asian and African Studies. 
Akins, J. E. (1973). The oil crisis: This time the wolf is here. Foreign Affairs, 51(3), 462-490. https://doi.org/10.2307/20037995

Anderson, E., \& Weitz, B. (1989). Determinants of continuity in conventional industrial channel dyads. Marketing Science, 8(4), 310-323. https://doi.org/10.1287/mksc.8.4.310

Anderson, E., \& Weitz, B. (1992). The use of pledges to build and sustain commitment in distribution channels. Journal of Marketing Research, 18-34. https://doi.org/10.2307/3172490

Anderson, J. C., \& Narus, J. A. (1990). A model of distributor firm and manufacturer firm working partnerships. The Journal of Marketing, 42-58. https://doi.org/10.2307/1252172

Anderson, L. A., DeVellis, B. M., \& DeVellis, R. F. (1987). Effects of modeling on patient communication, satisfaction, and Medical $\quad$ knowledge. https://doi.org/10.1097/00005650-198711000-00003

Apata, T. (2010). Linkages between crude-oil exploration and agricultural development in Nigeria: Implications for relevant qualitative data collection and analysis to improve rural economy. Third Wye City Group Conference on Agricultural and Rural Household Statistics Economic Research Service, may, 24-25.

Arezki, R., \& Blanchard, O. (2015). The 2014 oil price slump: Seven key questions. VOXEU, January, 13.

Athanasopoulou, P. (2009). Relationship quality: A critical literature review and research agenda. European Journal of Marketing, 43(5/6), 583-610. https://doi.org/10.1108/03090560910946945

Athanassopoulou, P. (2006). Determining relationship quality in the development of business-to-business financial services. Journal of Business-to-Business Marketing, 13(1), 87-120. https://doi.org/10.1300/J033v13n01_03

Beckman, B. (1982). Whose state? State and capitalist development in Nigeria. Review of African Political Economy, 9(23), 37-51.https://doi.org/10.1080/03056248208703487

Bejou, D., Wray, B., \& Ingram, T. N. (1996). Determinants of relationship quality: An artificial neural network analysis. Journal of Business Research, 36(2), 137-143. https://doi.org/10.1016/0148-2963(95)00100-X

Berry, L. L. (1983). Relationship marketing.

Berry, L. L., \& Parasuraman, A. (1991). Marketing service. Competing through Quality, New York,

Blankenburg, D., \& Johanson, J. (1992). Managing network connections in international business. Scandinavian International Business Review, 1(1), 5-19. https://doi.org/10.1016/0962-9262(92)90033-3

Blumstein, P., \& Kollock, P. (1988). Personal relationships. Annual Review of Sociology, 467-490. https://doi.org/10.1146/annurev.so.14.080188.002343

Boles, J. S., Barksdale, H. C., \& Johnson, J. T. (1997). Business relationships: An examination of the effects of buyer-salesperson relationships on customer retention and willingness to refer and recommend. Journal of Business \& Industrial Marketing, 12(3/4), 253-264. https://doi.org/10.1108/08858629710188072

Boles, J. S., Johnson, J. T., \& Barksdale, H. C. (2000). How salespeople build quality relationships:: A replication and extension. Journal of Business Research, 48(1), 75-81. https://doi.org/10.1016/S0148-2963(98)00078-2

Bowen, J. T., \& Shoemaker, S. (1998). Loyalty: A strategic commitment. Cornell Hotel and Restaurant Administration Quarterly, 39(1), 12-25. https://doi.org/10.1177/001088049803900104

Broom, G. M., Casey, S., \& Ritchey, J. (2000). Concept and theory of organization-public relationships. Public Relations as Relationship Management: A Relational Approach to the Study and Practice of Public Relations, 3-22.

Bryman, A., \& Bell, E. (2004). Research designs. Social Research Methods, 5.

Buttle, F. (1996). Relationship marketing: Theory and practice Sage. https://doi.org/10.4135/9781446252062

Cannon, J. P., \& Homburg, C. (2001). Buyer-supplier relationships and customer firm costs. Journal of Marketing, 65(1), 29-43. https://doi.org/10.1509/jmkg.65.1.29.18136

Chokor, B. A. (2004). Perception and response to the challenge of poverty and environmental resource degradation in rural Nigeria: Case study from the Niger delta. Journal of Environmental Psychology, 24(3), 305-318. https://doi.org/10.1016/j.jenvp.2004.08.001

Christopher, M., Payne, A., \& Ballantyne, D. (1991). Relationship marketing: Bringing quality customer service 
and marketing together.

Chumpitaz Caceres, R., \& Paparoidamis, N. G. (2007). Service quality, relationship satisfaction, trust, commitment and business-to-business loyalty. European Journal of Marketing, 41(7/8), 836-867. https://doi.org/10.1108/03090560710752429

Clark, M. S., \& Mils, J. (1993). The difference between communal and exchange relationships: What it is and is not. Personality and Social Psychology Bulletin, 19(6), 684-691. https://doi.org/10.1177/0146167293196003

Coombs, W. T. (2001). Interpersonal communication and public relations. Handbook of Public Relations, 105-114. https://doi.org/10.4135/9781452220727.n7

Coyne, I. T. (1997). Sampling in qualitative research. Purposeful and theoretical sampling; merging or clear $\begin{array}{llll}\text { boundaries? Journal of Advanced } & \text { Nursing, }\end{array}$ https://doi.org/10.1046/j.1365-2648.1997.t01-25-00999.x

Crosby, L. A., Evans, K. R., \& Cowles, D. (1990). Relationship quality in services selling: An interpersonal influence perspective. The Journal of Marketing, 68-81. https://doi.org/10.2307/1251817

Dorsch, M. J., Swanson, S. R., \& Kelley, S. W. (1998). The role of relationship quality in the stratification of vendors as perceived by customers. Journal of the Academy of Marketing Science, 26(2), 128-142. https://doi.org/10.1177/0092070398262004

Dwyer, F. R., \& Oh, S. (1987). Output sector munificence effects on the internal political economy of marketing channels. Journal of Marketing Research, 347-358. https://doi.org/10.2307/3151382

Ebegbulem, J., Ekpe, D., \& Adejumo, T. O. (2013). Oil exploration and poverty in the Niger delta region of Nigeria: A critical analysis. International Journal of Business and Social Science, 4(3), 279-287.

Ellis, S. (2003). Briefing: West africa and its oil. African Affairs, 102(406), 135-138. https://doi.org/10.1093/oxfordjournals.afraf.a138814

Elum, Z., Mopipi, K., \& Henri-Ukoha, A. (2016). Oil exploitation and its socioeconomic effects on the Niger delta region of Nigeria. Environmental Science and Pollution Research, 1-10. https://doi.org/10.1007/s11356-016-6864-1

Esfahani, H. S., Mohaddes, K., \& Pesaran, M. H. (2014). An empirical growth model for major oil exporters. Journal of Applied Econometrics, 29(1), 1-21. https://doi.org/10.1002/jae.2294

Eweje, G. (2006). Environmental costs and responsibilities resulting from oil exploitation in developing countries: The case of the Niger delta of Nigeria. Journal of Business Ethics, 69(1), 27-56. https://doi.org/10.1007/s10551-006-9067-8

Ford, D., Gadde, L., Håkansson, H., Snehota, I., \& Waluszewski, A. (2008). Analysing business interaction. 24th IMP Conference, Uppsala, 1-37.

Ford, J. K., Smith, E. M., Weissbein, D. A., Gully, S. M., \& Salas, E. (1998). Relationships of goal orientation, metacognitive activity, and practice strategies with learning outcomes and transfer. Journal of Applied Psychology, 83(2), 218. https://doi.org/10.1037/0021-9010.83.2.218

Fornell, C. (1992). A national customer satisfaction barometer: The swedish experience. The Journal of Marketing, 6-21. https://doi.org/10.2307/1252129

Franzosi, R. (2004). From words to numbers: Narrative, data, and social science Cambridge University Press.

Freeman, L. C. (1984). The impact of computer based communication on the social structure of an emerging scientific specialty. SocialNetworks, 6(3), 201-221. https://doi.org/10.1016/0378-8733(84)90011-X

Frynas, J. G. (2001). Corporate and state responses to anti-oil protests in the Niger delta. African Affairs, 100(398), 27-54. https://doi.org/10.1093/afraf/100.398.27

Fynes, B., De Burca, S., \& Marshall, D. (2004). Environmental uncertainty, supply chain relationship quality and performance. Journal of Purchasing and Supply Management, 10(4), 179-190. https://doi.org/10.1016/j.pursup.2004.11.003

Fynes, B., Voss, C., \& de Búrca, S. (2005). The impact of supply chain relationship quality on quality performance. International Journal of Production Economics, 96(3), 339-354. https://doi.org/10.1016/j.jpe.2004.05.008 
Ganesan, S. (1994). Determinants of long-term orientation in buyer-seller relationships. The Journal of Marketing, 1-19. https://doi.org/10.2307/1252265

Garbarino, E., \& Johnson, M. S. (1999). The different roles of satisfaction, trust, and commitment in customer relationships. The Journal of Marketing, 70-87. https://doi.org/10.2307/1251946

Giraud, G., \& Renouard, C. (2010). Mesurer la contribution des entreprises extractives au développement local. le cas des pétroliers au nigeria. Revue Française De Gestion, 208, 101. https://doi.org/10.3166/rfg.208-209.101-115

Glaser, B. G. (1978). Theoretical sensitivity: Advances in the methodology of grounded theory Sociology Pr.

Golicic, S. L., \& Mentzer, J. T. (2005). Exploring the drivers of interorganizational relationship magnitude. Journal of Business Logistics, 26(2), 47-71. https://doi.org/10.1002/j.2158-1592.2005.tb00205.x

Griswold, D. (2003). Clearinghouse that Enables Physicians to Submit Prescriptions Securely Over the Internet to a Pharmacy Patients can also Access their Prescription Data Over the Internet.

Grönroos, C. (1994). From marketing mix to relationship marketing: Towards a paradigm shift in marketing. Management Decision, 32(2), 4-20. https://doi.org/10.1108/00251749410054774

Grönroos, C. (2000). Creating a relationship dialogue: Communication, interaction and value. The Marketing Review, 1(1), 5-14. https://doi.org/10.1362/1469347002523428

Grunig, J. E. (2002). Qualitative methods for assessing relationships: Between organizations and publics.

Gummesson, E. (1987). The new marketing-developing long-term interactive relationships. Long Range Planning, 20(4), 10-20. https://doi.org/10.1016/0024-6301(87)90151-8

Gummesson, E. (1995). Relationship marketing: From 4Ps to 30Rs. Malmö: Liber-Hermods.

Gummesson, E. (2000). Internal marketing in the light of relationship marketing and network organizations. Internal Marketing: Directions for Management, 27-42. https://doi.org/10.4324/9780203207352.pt2

Gummesson, E. (2000). Qualitative methods in management research Sage.

Gummesson, E. (2002). Total relationship marketing: Marketing management, relationship strategy and CRM approaches for the network economy. Total Relationship Marketing: Marketing Management, Relationship Strategy and CRM Approaches for the Network Economy.

Gummesson, E. (2004). Return on relationships (ROR): The value of relationship marketing and CRM in business-to-business contexts. Journal of Business \& Industrial Marketing, 19(2), 136-148. https://doi.org/10.1108/08858620410524016

Gundlach, G. T., Achrol, R. S., \& Mentzer, J. T. (1995). The structure of commitment in exchange. The Journal of Marketing, 78-92.https://doi.org/10.2307/1252016

Hakansson, H., \& Snehota, I. (1995). Developing relationships in business networks Routledge London.

Hakansson, N. H. (1982). To pay or not to pay dividend. The Journal of Finance, 37(2), 415-428. https://doi.org/10.1111/j.1540-6261.1982.tb03564.x

Halinen, A., Salmi, A., \& Havila, V. (1999). From dyadic change to changing business networks: An analytical framework. Journal of Management Studies, 36(6), 779-794. https://doi.org/10.1111/1467-6486.00158

Harris, H. (2001). Content analysis of secondary data: A study of courage in managerial decision making. Journal of Business Ethics, 34(3-4), 191-208. https://doi.org/10.1023/A:1012534014727

Hennig-Thurau, T., \& Klee, A. (1997). The impact of customer satisfaction and relationship quality on customer retention: A critical reassessment and model de velopment. Psychology \& Marketing, 14(8), 737-764. https://doi.org/10.1002/(SICI)1520-6793(199712)14:8<737::AID-MAR2>3.0.CO;2-F

Hennig-Thurau, T., Gwinner, K. P., \& Gremler, D. D. (2002). Understanding relationship marketing outcomes an integration of relational benefits and relationship quality. Journal of Service Research, 4(3), 230-247. https://doi.org/10.1177/1094670502004003006

Hennig-Thurau, T., Langer, M. F., \& Hansen, U. (2001). Modeling and managing student loyalty an approach based on the concept of relationship quality. Journal of Service Research, 3(4), 331-344. https://doi.org/10.1177/109467050134006

Hinde, R. A. (1981). The bases of a science of interpersonal relationships. Personal Relationships, 1,1-22. 
Hinde, R. A., \& Tajfel, H. (1979). Towards understanding relationships Academic Press London.

Holmen, E., Pedersen, A., \& Torvatn, T. (2005). Building relationships for technological innovation. Journal of Business Research, 58(9), 1240-1250. https://doi.org/10.1016/j.jbusres.2003.10.010

Holmlund, M. (2001). The D\&D model-dimensions and domains of relationship quality perceptions. Service Industries Journal, 21(3), 13-36. https://doi.org/10.1080/714005036

Hon, L. C., \& Grunig, J. E. (1999). Guidelines for measuring relationships in public relations.

Hsieh, H. F., \& Shannon, S. E. (2005). Three approaches to qualitative content analysis. Qualitative Health Research, 15(9), 1277-1288. https://doi.org/10.1177/1049732305276687

Hung, C. F. (2005). Exploring types of organization-public relationships and their implications for relationship management in public relations. Journal of Public Relations Research, 17(4), 393-426. https://doi.org/10.1207/s1532754xjprr1704_4

Huntley, J. K. (2006). Conceptualization and measurement of relationship quality: Linking relationship quality to actual sales and recommendation intention. Industrial Marketing Management, 35(6), 703-714. https://doi.org/10.1016/j.indmarman.2005.05.011

Idemudia, U. (2007). Community perceptions and expectations: Reinventing the wheels of corporate social responsibility practices in the Nigerian oil industry. Business and Society Review, 112(3), 369-405. https://doi.org/10.1111/j.1467-8594.2007.00301.x

Idemudia, U. (2014a). Corporate-community engagement strategies in the Niger delta: Some critical reflections'. The Extractive Industries and Society, 1 (2), 154-162. https://doi.org/10.1016/j.exis.2014.07.005

Idemudia, U. (2014b). Corporate social responsibility and development in Africa: Issues and possibilities. Geography Compass, 8(7), 421-435. https://doi.org/10.1111/gec3.12143

Idemudia, U. (2016). Environmental Business-NGO partnerships in Nigeria: Issues and prospects. Business Strategy and the Environment.

Ikein, A. A. (2016). Nigeria oil \& external exposure: The crude gains and crude pains of crude export dependence economy. The Business \& Management Review, 7(3), 109.

Ikelegbe, A. (2001). Civil society, oil and conflict in the Niger delta region of Nigeria: Ramifications of civil society for a regional resource struggle. The Journal of Modern African Studies, 39(03), 437-469. https://doi.org/10.1017/S0022278X01003676

Ikporukpo, C. (1983). Petroleum exploitation and the socio-economic environment in Nigeria. International Journal of Environmental Studies, 21 (2), 193-203. https://doi.org/10.1080/00207238308710076

Ite, A. E., Ibok, U. J., Ite, M. U., \& Petters, S. W. (2013). Petroleum exploration and production: Past and present environmental issues in the Nigeria's Niger delta. American Journal of Environmental Protection, 1(4), 78-90. https://doi.org/10.12691/env-1-4-2

Ivens, B. S., \& Pardo, C. (2007). Are key account relationships different? Empirical results on supplier strategies and customer reactions. Industrial Marketing Management, 36(4), 470-482. https://doi.org/10.1016/j.indmarman.2005.12.007

Jacques, E. (1951). The changing culture of a factory: A study of authority and participation in an industrial setting. London: Tavistock.

Jap, S. D., \& Anderson, E. (2007). Testing a life-cycle theory of cooperative inter organisational relationships: Movement across stages and performance. Management Science, 53(2), 260-275. https://doi.org/10.1287/mnsc. 1060.0610

Jap, S. D., Manolis, C., \& Weitz, B. A. (1999). Relationship quality and buyer-seller interactions in channels of distribution. Journal of Business Research, 46(3), 303-313. https://doi.org/10.1016/S0148-2963(98)00032-0

Johnson, J. L. (1999). Strategic integration in industrial distribution channels: Managing the interfirm relationship as a strategic asset. Journal of the Academy of Marketing Science, 27(1), 4-18. https://doi.org/10.1177/0092070399271001

Johnson, M. D., \& Selnes, F. (2004). Customer portfolio management: Toward a dynamic theory of exchange relationships. Journal of Marketing, 68(2), 1-17. https://doi.org/10.1509/jmkg.68.2.1.27786

Kadafa, A. A. (2012). Oil exploration and spillage in the Niger delta of Nigeria. Civil and Environmental 
Research, 2(3), 38-51.

Kalwani, M. U., \& Narayandas, N. (1995). Long-term manufacturer-supplier relationships: Do they pay off for supplier firms? The Journal of Marketing, 1-16. https://doi.org/10.2307/1252010

Kaplan, A. (1943). Content analysis and the theory of signs. Philosophy of Science, 10(4), 230-247. https://doi.org/10.1086/286814

Karantinou, K. M., \& Hogg, M. K. (2009). An empirical investigation of relationship development in professional business services. Journal of Services Marketing, 23(4), 249-260. https://doi.org/10.1108/08876040910965584

Keating, B., Rugimbana, R., \& Quazi, A. (2003). Differentiating between service quality and relationship quality in cyberspace. Managing Service Quality: An International Journal, 13(3), 217-232. https://doi.org/10.1108/09604520310476481

Keating, B. W., Alpert, F., Kriz, A., \& Quazi, A. (2011). Mediating role of relationship quality in online services. Journal of Computer Information Systems, 52(2), 33-41.

Kempeners, M. (1995). Relationship quality in business-to-business relationships. Proceedings of the 11th IMP Conference, 3, 1629-1639.

Khan, S. A. (1994). Nigeria: The political economy of oil.

Kilburn, A. J., \& Kilburn, B. R. (2008). Internal relationship quality: The impact of relationship quality on internal customer perceptions. Academy of Marketing Studies Journal, 12(1), 43.

Knobloch, L. K., \& Knobloch-Fedders, L. M. (2010). The role of relational uncertainty in depressive symptoms and relationship quality An actor-partner interdependence model. Journal of Social and Personal Relationships, 27(1), 137-159. https://doi.org/10.1177/0265407509348809

Kotler, P., \& Armstrong, G. (2010). Principles of marketing. pearson education.

Kühne, B., Gellynck, X., \& Weaver, R. D. (2013). The influence of relationship quality on the innovation capacity in traditional food chains. Supply Chain Management: An International Journal, 18(1), 52-65. https://doi.org/10.1108/13598541311293177

Kumar, N., Scheer, L. K., \& Steenkamp, J. E. (1995). The effects of supplier fairness on vulnerable resellers. Journal of Marketing Research, 54-65. https://doi.org/10.2307/3152110

LaBahn, D. W., \& Kohli, C. (1997). Maintaining client commitment in advertising agency-client relationships. Industrial Marketing Management, 26(6), 497-508. https://doi.org/10.1016/S0019-8501(97)00025-4

Lagace, R. R., Dahlstrom, R., \& Gassenheimer, J. B. (1991). The relevance of ethical salesperson behavior on relationship quality: The pharmaceutical industry. Journal of Personal Selling \& Sales Management, 11(4), $39-47$.

Lages, C., Lages, C. R., \& Lages, L. F. (2005). The RELQUAL scale: A measure of relationship quality in export market ventures. Journal of Business Research, 58(8), 1040-1048. https://doi.org/10.1016/j.jbusres.2004.03.001

Lai, I. K. W. (2014). The role of service quality, perceived value, and relationship quality in enhancing customer loyalty in the travel agency sector. Journal of Travel \& Tourism Marketing,31(3), 417-442. https://doi.org/10.1080/10548408.2014.883346

Lang, B., \& Colgate, M. (2003). Relationship quality, on-line banking and the information technology gap. International Journal of Bank Marketing, 21(1), 29-37. https://doi.org/10.1108/02652320310457785

Law, M., Lau, T., \& Wong, Y. (2003). From customer relationship management to customer-managed relationship: Unraveling the paradox with a co-creative perspective. Marketing Intelligence \& Planning, 21(1), 51-60. https://doi.org/10.1108/02634500310458153

Ledingham, J. A. (2003). Explicating relationship management as a general theory of public relations. Journal of Public Relations Research, 15(2), 181-198. https://doi.org/10.1207/S1532754XJPRR1502_4

Ledingham, J. A., \& Bruning, S. D. (1998). Relationship management in public relations: Dimensions of an organization-public relationship. Public Relations Review, 24(1), 55-65. https://doi.org/10.1016/S0363-8111(98)80020-9 
Leonidou, C. N., Leonidou, L. C., Coudounaris, D. N., \& Hultman, M. (2013). Value differences as determinants of importers' perceptions of exporters' unethical behavior: The impact on relationship quality and performance. International Business Review, 22(1), 156-173. https://doi.org/10.1016/j.ibusrev.2012.03.005

Leonidou, L. C., Barnes, B. R., \& Talias, M. A. (2006). Exporter-importer relationship quality: The inhibiting role of uncertainty, distance, and conflict. Industrial Marketing Management,35(5), 576-588. https://doi.org/10.1016/j.indmarman.2005.06.012

Leuthesser, L. (1997). Supplier relational behavior: An empirical assessment. Industrial marketing management, 26(3), 245-254. https://doi.org/10.1016/S0019-8501(96)00092-2

Levitt, T. (1986). Marketing imagination: New Simon and Schuster.

Liang, T. P., Ho, Y. T., Li, Y. W., \& Turban, E. (2011). What drives social commerce: The role of social support and relationship quality. International Journal of Electronic Commerce, 16(2), 69-90. https://doi.org/10.2753/JEC1086-4415160204

Lin, S. (2013). The influence of relational selling behavior on relationship quality: The moderating effect of perceived price and customers' relationship proneness. Journal of Relationship Marketing, 12(3), 204-222. https://doi.org/10.1080/15332667.2013.816931

Lo, A. S. Y., \& Im, H. H. (2014). Drivers of Customer-Brand Relationship Quality: ACase of Mainland Chinese Hotel Loyalty Program Members. Journal of Travel \& Tourism Marketing,31(7), 763-782. https://doi.org/10.1080/10548408.2014.889638

MacNeil, 1. (1978). Contracts: Adjustment of long-term economic relations under classical, neoclassical, and relational contract law, Northwestern University Law Review, 854-905.

MacNeil, R. D. (1980). The relationship of cognitive style and instructional style to the learning performance of undergraduate students. The Journal of Educational Research, 73(6), 354-359. https://doi.org/10.1080/00220671.1980.10885265

Marquardt, A. J. (2013). Relationship quality as a resource to build industrial brand equity when products are uncertain and future-based. Industrial Marketing Management,42(8), 1386-1397. https://doi.org/10.1016/j.indmarman.2013.07.017

McNamara, C. (1999). General guidelines for conducting interviews, Minnesota. Missouri Institute of Science,

McQuiston, D. H. (2001). A conceptual model for building and maintaining relationships between manufacturers' representatives and their principals. Industrial Marketing Management, 30(2), 165-181. https://doi.org/10.1016/S0019-8501(00)00141-3

Medlin, C. J., Aurifeille, J., \& Quester, P. G. (2005). A collaborative interest model of relational coordination and empirical results. Journal of Business Research, 58(2), 214-222. https://doi.org/10.1016/S0148-2963(02)00496-4

Men, L. R. (2011). How employee empowerment influences organization-employee relationship in china. Public Relations Review, 37(4), 435-437. https://doi.org/10.1016/j.pubrev.2011.08.008

Menon, A., Bharadwaj, S. G., \& Howell, R. (1996). The quality and effectiveness of marketing strategy: Effects of functional and dysfunctional conflict in intraorganizational relationships. Journal of the Academy of Marketing Science, 24(4), 299-313. https://doi.org/10.1177/0092070396244002

Möller, K. K., \& Törrönen, P. (2003). Business suppliers' value creation potential: A capability-based analysis. Industrial Marketing Management, 32(2), 109-118. https://doi.org/10.1016/S0019-8501(02)00225-0

Moorman, C., Zaltman, G., \& Deshpande, R. (1992). Relationships between providers and users of market research: The dynamics of trust within and between organizations. Journal of Marketing Research, 29(3), 314. https://doi.org/10.2307/3172742

Morgan, R. M., \& Hunt, S. D. (1994). The commitment-trust theory of relationship marketing. Journal of Marketing, 58(3).

Morris, M. H., Koçak, A., \& Özer, A. (2007). Coopetition as a small business strategy: Implications for performance. Journal of Small Business Strategy, 18(1), 35.

Morry, M. M., \& Kito, M. (2009). Relational-interdependent self-construal as a predictor of relationship quality: The mediating roles of one's own behaviors and perceptions of the fulfillment of friendship functions. The Journal of social psychology, 149(3), 305-322. https://doi.org/10.3200/SOCP.149.3.305-322 
Morry, M. M., Reich, T., \& Kito, M. (2010). How do I see you relative to myself? Relationship quality as a predictor of self-and partner-enhancement within cross-sex friendships, dating relationships, and marriages. The Journal of social psychology, 150(4), 369-392. https://doi.org/10.1080/00224540903365471

Naudé, P., \& Buttle, F. (2000). Assessing relationship quality. Industrial Marketing Management, 29(4), 351-361. https://doi.org/10.1016/S0019-8501(00)00112-7

Naudé, P., Ashnai, B., Chaharsooghi, K., \& Perzon, H. (2007). An analysis of B2B relationship quality among Iranian managers: A comparison between Iranian and English managers. Total Quality Management \& Business Excellence, 18(8), 861-874. https://doi.org/10.1080/14783360701350508

Ndubisi, N. (2006). Effect of gender on customer loyalty: a relationship marketing approach. Marketing Intelligence \& Planning, 24(1), 48-61. https://doi.org/10.1108/02634500610641552

Ndubisi, N. O., Malhotra, N. K., Ulas, D., \& Ndubisi, G. C. (2012). Examining uncertainty avoidance, relationship quality, and customer loyalty in two cultures. Journal of International Consumer Marketing, 24(5), 320-337. https://doi.org/10.1080/08961530.2012.741477

Nguyen, T. T., \& Nguyen, T. D. (2014). Enhancing business relationship quality through cultural sensitization. Journal of Relationship Marketing, 13(1), 70-87. https://doi.org/10.1080/15332667.2014.882177

Nriagu, J., Udofia, E. A., Ekong, I., \& Ebuk, G. (2016). Health risks associated with oil pollution in the Niger delta, Nigeria. International Journal of Environmental Research and Public Health, 13(3), 346. https://doi.org/10.3390/ijerph13030346

Nyengidiki, T., \& Allagoa, D. (2011). Rupture of the gravid uterus in a tertiary health facility in the Niger delta region of Nigeria: A 5-year review. Nigerian Medical Journal, 52(4), 230. https://doi.org/10.4103/0300-1652.93794

Obi, C. (2014). Oil and conflict in Nigeria's Niger delta region: Between the barrel and the trigger. The Extractive Industries and Society, 1(2), 147-153. https://doi.org/10.1016/j.exis.2014.03.001

Oliver, C. (1997). Sustainable competitive advantage: Combining institutional and resource-based views. Strategic Management Journal, 18(9), 697-713. https://doi.org/10.1002/(SICI)1097-0266(199710)18:9<697::AID-SMJ909>3.0.CO;2-C

Oliver, R. L. (1999). Whence consumer loyalty? The Journal of Marketing, 33-44. https://doi.org/10.2307/1252099

Oliver, R. L. (2010). Customer satisfaction. Wiley International Encyclopedia of Marketing. https://doi.org/10.1002/9781444316568.wiem03008

Olobaniyi, S. B., \& Omo-Irabor, O. O. (2016). Environmental impact assessment of selected oil production facilities in parts of Niger delta, Nigeria. Journal of Water Resource and Protection, 8(02), 237. https://doi.org/10.4236/jwarp.2016.82020

Omilion-Hodges, L. M., \& Baker, C. R. (2013). Contextualizing LMX within the workgroup: The effects of LMX and justice on relationship quality and resource sharing among peers. The Leadership Quarterly, 24(6), 935-951. https://doi.org/10.1016/j.leaqua.2013.10.004

Omofonmwan, S. I., \& Odia, L. O. (2009). Oil exploitation and conflict in the Niger-delta region of Nigeria. Journal of Human Ecology, 26(1), 25-30.

Onemolease, E., \& Alakpa, S. (2009). Determinants of adoption decisions of rural youths in the Niger delta region of Nigeria. Journal of Social Sciences, 20(1), 61-66.

Osaghae, E. E. (2015). Resource curse or resource blessing: The case of the Niger delta 'oil republic'in Nigeria. Commonwealth \& Comparative Politics, 53(2), 109-129. https://doi.org/10.1080/14662043.2015.1013297

Osaghae, E., Ikelegbe, A., Olarinmoye, O., \& Okhomina, S. (2007). Youth militias, self-determination and resource control struggles in the Niger-delta region of Nigeria. Unpublished Mimeograph,

Osobajo, O. A., \& Moore, D. R. (2016). Methodological choices in Relationship Quality (RQ) research 1987 to 2015: Asystematic literature review. (Accepted by Journal of Relationship Marketing for publication)

Palmatier, R. W., Dant, R. P., Grewal, D., \& Evans, K. R. (2006). Factors influencing the effectiveness of relationship marketing: A meta-analysis. Journal of Marketing, 70(4), 136-153. https://doi.org/10.1509/jmkg.70.4.136

Parahoo, K. (2006). Nursing research: Principles, process and issues Palgrave Macmillan. 
Park, J. E., \& Deitz, G. D. (2006). The effect of working relationship quality on salesperson performance and job satisfaction: Adaptive selling behavior in Korean automobile sales representatives. Journal of Business Research,59(2), 204-213. https://doi.org/10.1016/j.jbusres.2005.04.002

Park, J. E., Kim, J., Dubinsky, A. J., \& Lee, H. (2010). How does sales force automation influence relationship quality and performance? The mediating roles of learning and selling behaviors. Industrial marketing management, 39(7), 1128-1138. https://doi.org/10.1016/j.indmarman.2009.11.003

Parsons, A. L. (2002). What determines buyer-seller relationship quality? An investigation from the buyer's $\begin{array}{llllll}\text { perspective. Journal of Supply Chain } & \text { Management, } & 38(1), & \text { 4-12. }\end{array}$ https://doi.org/10.1111/j.1745-493X.2002.tb00124.x

Petrican, R., Burris, C. T., Bielak, T., Schimmack, U., \& Moscovitch, M., 2011. For my eyes only: Gaze control, enmeshment, and relationship quality. Journal of personality and social psychology, 100(6), 1111. https://doi.org/10.1037/a0021714

Polit, D. F., \& Beck, C. T. (2009). International gender bias in nursing research, 2005-2006: A quantitative content analysis. International Journal of Nursing Studies, 46(8), 1102-1110. https://doi.org/10.1016/j.ijnurstu.2009.02.002

Prinsloo, M., Bäckström, L., \& Salehi-Sangari, E. (2007). The impact of incentives on interfunctional relationship quality: Views from a South African firm. Total Quality Management \& Business Excellence, 18(8), 901-913. https://doi.org/10.1080/14783360701350870

Puyate, Y., \& Rim-Rukeh, A. (2008). Some physico-chemical and biological characteristics of soil and water samples of part of the Niger delta area, Nigeria. Journal of Applied Sciences and Environmental Management, 12(2).

Rafiq, M., Fulford, H., \& Lu, X. (2013). Building customer loyalty in online retailing: The role of relationship quality. Journal of Marketing Management, 29(3-4), 494-517. https://doi.org/10.1080/0267257X.2012.737356

Ramaseshan, B., Yip, L. S. \& Pae, J. H. (2006). Power, satisfaction, and relationship commitment in Chinese store-tenant relationship and their impact on performance. Journal of Retailing, 82(1), 63-70. https://doi.org/10.1016/j.jretai.2005.11.004

Rašković, M., \& Mörec, B. (2013). Determinants of supplier-buyer relationship competitiveness in transnational companies. Economic and Business Review, 15(1), 5-31.

Rauyruen, P., \& Miller, K. E. (2007). Relationship quality as a predictor of B2B customer loyalty. Journal of Business Research, 60(1), 21-31. https://doi.org/10.1016/j.jbusres.2005.11.006

Renouard, C. (2010). Le Nigeria et la malédiction des ressources. Études, 413(10), 307-318.

Renouard, C. (2011). Corporate social responsibility, utilitarianism, and the capabilities approach. Journal of Business Ethics, 98(1), 85-97. https://doi.org/10.1007/s10551-010-0536-8

Renouard, C., \& Lado, H. (2012). CSR and inequality in the Niger Delta (Nigeria). Corporate Governance: The international journal of business in society, 12(4), 472-484. https://doi.org/10.1108/14720701211267810

Rhodes, M., \& Suleiman, T. (2013). The importance of oil to an export dependent economy: The case of Nigeria. Available at SSRN2307636,

Roberts, K., Varki, S., \& Brodie, R. (2003). Measuring the quality of relationships in consumer services: An empirical study. European Journal of Marketing, 37(1/2), 169-196. https://doi.org/10.1108/03090560310454037

Ross, M. (2012). The oil curse: How petroleum wealth shapes the development of nations Princeton University Press.

Ross, M. L. (2003). Nigeria's oil sector and the poor. Position Paperfor DFID-Nigeria, UCLA, Los Angeles,

Rusbult, C. E. (1983). A longitudinal test of the investment model: The development (and deterioration) of satisfaction and commitment in heterosexual involvements. Journal of Personality and Social Psychology, 45(1), 101-117. https://doi.org/10.1037/0022-3514.45.1.101

Rust, R. T., Ambler, T., Carpenter, G. S., Kumar, V., \& Srivastava, R. K. (2004). Measuring marketing productivity: Current knowledge and future directions. Journal of Marketing, 68(4), 76-89. https://doi.org/10.1509/jmkg.68.4.76.42721 
Sandelowski, M., Holditch-Davis, D., \& Harris, B. G. (1992). Using qualitative and quantitative methods: The transition to parenthood of infertile couples. Qualitative Methods in Family Research, 301-322.

Sanzo, M. J., Santos, M. L., Vázquez, R., \& Álvarez, L. I. (2003). The effect of market orientation on buyerseller relationship satisfaction. Industrial Marketing Management, 32(4), 327-345. https://doi.org/10.1016/S0019-8501(01)00200-0

Scanlan, L., \& McPhail, J. (2000). Forming service relationships with hotel business travelers: The critical attributes to improve retention. Journal of Hospitality \& Tourism Research, 24(4), 491-513. https://doi.org/10.1177/109634800002400405

Selnes, F. (1998). Antecedents and consequences of trust and satisfaction in buyer-seller relationships. European journal of marketing, 32(3/4), 305-322. https://doi.org/10.1108/03090569810204580

Semrau, T., \& Werner, A. (2014). How Exactly Do Network Relationships Pay Off? The Effects of Network Size and Relationship Quality on Access to Start - Up Resources. Entrepreneurship Theory and Practice, 38(3), 501-525. https://doi.org/10.1111/etap.12011

Shabbir, H., Palihawadana, D., \& Thwaites, D. (2007). Determining the antecedents and consequences of donor - perceived relationship quality-A dimensional qualitative research approach. Psychology \& Marketing, 24(3), 271-293. https://doi.org/10.1002/mar.20161

Sheth, J. N., \& Parvatiyar, A. (2002). Evolving relationship marketing into a discipline. Journal of Relationship Marketing, 1(1),3-16. https://doi.org/10.1300/J366v01n01_02

Sheu, J. B. (2015). Power shifts and relationship quality improvement of producer-retailer green channel dyads under government intervention. Industrial Marketing Management, 50, 97-116. https://doi.org/10.1016/j.indmarman.2015.04.010

Skarmeas, D., \& Robson, M. J. (2008). Determinants of relationship quality in importer-exporter relationships. British Journal of Management, 19(2), 171-184. https://doi.org/10.1111/j.1467-8551.2007.00537.x

Smith, B. (1998a). Buyer-Seller relationships: Bonds, relationship management, and Sex-Type. Canadian Journal of Administrative Sciences/Revue Canadienne Des Sciences De l'Administration, 15(1), 76-92.

Smith, J. B. (1998b). Buyer-seller relationships: Similarity, relationship management, and quality. Psychology \& Marketing, 15(1), 3-21. https://doi.org/10.1002/(SICI)1520-6793(199801)15:1<3::AID-MAR2>3.0.CO;2-I

Smyth, H., Gustafsson, M., \& Ganskau, E. (2010). The value of trust in project business. International Journal of Project Management, 28(2), 117-129. https://doi.org/10.1016/j.ijproman.2009.11.007

Spencer, L., Ritchie, J., Lewis, J., \& Dillon, L. (2003). Quality in qualitative evaluation: A framework for assessing research evidence.

Stafford, L., \& Canary, D. J. (1991). Maintenance strategies and romantic relationship type, gender and relational

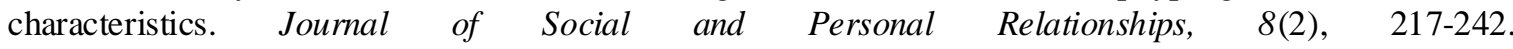
https://doi.org/10.1177/0265407591082004

Storbacka, K., Strandvik, T., \& Grönroos, C. (1994). Managing customer relationships for profit: The dynamics of relationship quality. International Journal of Service Industry Management, 5(5), 21-38. https://doi.org/10.1108/09564239410074358

Subramony, M. (2014). Client supportiveness in contingent employment: The role of relationship quality. European Journal of Work and Organizational Psychology, 23(1), 131-144. https://doi.org/10.1080/1359432X.2012.718116

Tareque, A. M., \& Azila, M. N. N. (2013). Evaluating the effect of cost related factors on relationship quality: An investigation of retailer-supplier relationship in Bangladesh. International Journal of Retail \& Distribution Management, 41(7), 545-558. https://doi.org/10.1108/IJRDM-05-2013-0098

Teece, D. J., Pisano, G., \& Shuen, A. (1997). Dynamic capabilities and strategic management. Strategic Management Journal, 509-533. https://doi.org/10.1002/(SICI)1097-0266(199708)18:7<509::AID-SMJ882>3.0.CO;2-Z

Tobor, J. O., \& Muzorewa, W. (2016). A comparative analysis of the Niger delta crisis in Nigeria and the land reform process in zimbabwe. European Journal of Research and Reflection in Educational Sciences, 4(4).

Tripathi, G., \& Dave, K. (2013). Store format choice and relationship quality in apparel retail: A study of young and early-middle aged shoppers in New Delhi region. Journal of Retailing and Consumer Services, 20(5), 
479-487. https://doi.org/10.1016/j.jretconser.2013.04.003

Tung, B., \& Carlson, J. (2013). Modeling a formative measure of relationship quality and its effects: Evidence from the Hong Kong retail banking industry. Services Marketing Quarterly, 34(2), 139-158. https://doi.org/10.1080/15332969.2013.770674

Turnbull, P. W., \& Valla, J. (1986). Strategic planning in industrial marketing: An interaction approach. European Journal of Marketing, 20(7), 5-20. https://doi.org/10.1108/EUM0000000004652

Turnbull, P., Ford, D., \& Cunningham, M. (1996). Interaction, relationships and networks in business markets: An evolving perspective. Journal of Business \& Industrial Marketing, 11(3/4), 44-62. https://doi.org/10.1108/08858629610125469

Ubani, E., \& Onyejekwe, I. (2013). Environmental impact analysis of gas flaring in the Niger delta region of Nigeria. American J.of Scientific and Industrial Research, 4(2), 246-252. https://doi.org/10.5251/ajsir.2013.4.2.246.252

Uchino, B. N., Smith, T. W., \& Berg, C. A. (2014). Spousal relationship quality and cardiovascular risk dyadic perceptions of relationship ambivalence are associated with coronary-artery calcification. Psychological science, 25(4), 1037-1042. https://doi.org/10.1177/0956797613520015

Ulaga, W., \& Eggert, A. (2006). Relationship value and relationship quality: Broadening the nomological network of business-to-business relationships. European Journal of Marketing, 40(3/4), 311-327. https://doi.org/10.1108/03090560610648075

Van Bruggen, G. H., Kacker, M., \& Nieuwlaat, C. (2005). The impact of channel function performance on buyer-seller relationships in marketing channels. International Journal of Research in Marketing, 22(2), 141-158. https://doi.org/10.1016/j.jjresmar.2004.06.004

Venetis, K. A., \& Ghauri, P. N. (2004).. Service quality and customer retention: building long-term relationships. European Journal of marketing, 38(11/12), 1577-1598. https://doi.org/10.1108/03090560410560254

Vesel, P., \& Zabkar, V. (2010). Relationship quality evaluation in retailers' relationships with consumers. European Journal of Marketing, 44(9/10), 1334-1365. https://doi.org/10.1108/03090561011062871

Vidal, D. (2012). Does loyalty make customers blind? The impact of relationship quality on channel members' attributions and behaviors following negative critical incidents. Journal of Business-to-Business Marketing, 19(2), 97-128. https://doi.org/10.1080/1051712X.2012.621839

Vieira, A. L., Winklhofer, H., \& Ennew, C. T. (2008). Relationship quality: A literature review and research agenda. Journal of Customer Behaviour, 7(4), 269-291. https://doi.org/10.1362/147539208X386833

Vieira, A. L. (2009). Business-to-business relationship quality. Portuguese journal of management studies, 14(3), 197-216.

Vikas, G. (2011). An empirical study to understand the different antecedents of relationship quality in the Indian context with reference to the mobile telecommunication sector. Romanian Journal of Marketing, 6(1), 29.

Walter, A., Müller, T. A., Helfert, G., \& Ritter, T. (2003). Functions of industrial supplier relationships and their impact on relationship quality. Industrial Marketing Management, 32(2), 159-169. https://doi.org/10.1016/S0019-8501(02)00230-4

Watts, M. (2001). Petro-violence: Community, extraction, and political ecology of a mythic commodity. Violent Environments, 189-212.

Watts, M. (2004). Resource curse? Governmentality, oil and power in the Niger delta, Nigeria. Geopolitics, 9(1), 50-80. https://doi.org/10.1080/14650040412331307832

Weber, R. P. (1990). Basic content analysis Sage. https://doi.org/10.4135/9781412983488

Wilkinson, A. (1998). Empowerment: Theory and practice. Personnel Review, 27(1), 40-56. https://doi.org/10.1108/00483489810368549

Wilkinson, I., \& Young, L. (2002). On cooperating: Firms, relations and networks. Journal of Business Research, 55(2), 123-132. https://doi.org/10.1016/S0148-2963(00)00147-8

Wilson, D. T. (1995). An integrated model of buyer-seller relationships. Journal of the Academy of Marketing Science, 23(4), 335-345. https://doi.org/10.1177/009207039502300414

Wong, Y., Chan, R. Y., \& Leung, T. K. (2005). Managing information diffusion in internet marketing. European 
Journal of Marketing, 39(7/8), 926-946. https://doi.org/10.1108/03090560510601842

Woo, K., \& Ennew, C. T. (2004). Business-to-business relationship quality: An IMP interaction-based conceptualization and measurement. European Journal of Marketing, 38(9/10), 1252-1271. https://doi.org/10.1108/03090560410548960

Wulf, K. D., Odekerken-Schröder, G., \& Iacobucci, D. (2001). Investments in consumer relationships: A cross-country and cross-industry exploration. Journal of Marketing, 65(4), 33-50. https://doi.org/10.1509/jmkg.65.4.33.18386

Zabkar, V., \& Makovec Brencic, M. (2004). Values, trust, and commitment in business-to-business relationships: A comparison of two former Yugoslav markets. International Marketing Review, 21(2), 202-215. https://doi.org/10.1108/02651330410531402

Zimmerman, K. J., \& Roberts, C. W. (2012). The influence of a financial management course on couples' relationship quality. Journal of Financial Counselling and Planning, 23(2).

Zineldin, M. (1995). Bank-company interactions and relationships: Some empirical evidence. International Journal of Bank Marketing, 13(2), 30-40. https://doi.org/10.1108/02652329510078677

Zineldin, M. (2004). Co-opetition: The organisation of the future. Marketing Intelligence \& Planning, 22(7), 780-790. https://doi.org/10.1108/02634500410568600

Zineldin, M. A. (1998). Towards an ecological collaborative relationship management A. European Journal of Marketing, 32(11-12), 1138-1164. https://doi.org/10.1108/03090569810243767

Appendix A. Relationship Quality Constructs (summarised from the literature)

\begin{tabular}{|c|c|c|c|c|}
\hline Authors & Method & Relationship type & Industry & Constructs \\
\hline $\begin{array}{l}\text { Dwyer, Schurr \& } \\
\text { Oh, } 1987\end{array}$ & $\begin{array}{l}\text { Survey and random } \\
\text { sample }\end{array}$ & $\begin{array}{l}\text { Manufacturers } \\
\text { dealers i.e. sellers and } \\
\text { buyers }\end{array}$ & USA Automobile & $\begin{array}{l}\text { Trust, satisfaction, } \\
\text { minimal opportunity }\end{array}$ \\
\hline $\begin{array}{l}\text { Crosby et al., } \\
1990\end{array}$ & $\begin{array}{l}\text { Survey i.e. questionnaire } \\
\text { and random sample }\end{array}$ & $\begin{array}{l}\text { Sales people - retail } \\
\text { customers }\end{array}$ & $\begin{array}{l}\text { USA } \\
\text { insurance }\end{array}$ & Trust, satisfaction \\
\hline $\begin{array}{l}\text { Lagace et al., } \\
1991\end{array}$ & $\begin{array}{l}\text { Telephone request and } \\
\text { mailed questionnaires }\end{array}$ & $\begin{array}{lr}\text { physicians } & \text { and } \\
\text { Pharmaceutical } & \text { sales } \\
\text { people } & \\
\end{array}$ & Business & Trust, satisfaction \\
\hline $\begin{array}{l}\text { Moorman et al., } \\
1992\end{array}$ & $\begin{array}{l}\text { Survey i.e. questionnaire } \\
\text { and convenience sample }\end{array}$ & $\begin{array}{l}\text { Providers and users of } \\
\text { market research e.g } \\
\text { internal marketing } \\
\text { manager \& researcher }\end{array}$ & $\begin{array}{l}\text { Marketing } \\
\text { research }\end{array}$ & Trust, satisfaction \\
\hline Han et al., 1993 & $\begin{array}{l}\text { Survey i.e. questionnaire } \\
\text { and convenience sample }\end{array}$ & $\begin{array}{l}\text { buyers and suppliers e.g } \\
\text { Purchasing agents and } \\
\text { sales people }\end{array}$ & $\begin{array}{l}\text { Industrial } \\
\text { relationship }\end{array}$ & Trust, satisfaction \\
\hline $\begin{array}{l}\text { Johns on et al., } \\
1993\end{array}$ & $\begin{array}{l}\text { Survey i.e. mailed } \\
\text { questionnaire and } \\
\text { convenience sample }\end{array}$ & $\begin{array}{l}\text { Japanese distributors of } \\
\text { U.S. manufactured } \\
\text { consumer products and } \\
\text { U.S. suppliers }\end{array}$ & Consumer goods & $\begin{array}{l}\text { Satisfaction, } \\
\text { cooperation, stability }\end{array}$ \\
\hline Wray et al., 1994 & $\begin{array}{l}\text { Telephone survey and } \\
\text { random sample interview }\end{array}$ & $\begin{array}{l}\text { Financial intermediary } \\
\text { and customers of } \\
\text { financial service } \\
\text { intermediaries }\end{array}$ & Financial service & Trust, satisfaction \\
\hline $\begin{array}{l}\text { Morgan \& Hunt, } \\
1994\end{array}$ & $\begin{array}{l}\text { In-depth on-site } \\
\text { interview for preminary } \\
\text { study, questionnaire and } \\
\text { random sample }\end{array}$ & $\begin{array}{l}\text { Retailers and their } \\
\text { customers }\end{array}$ & Automobile & Trust, commitment \\
\hline Zineldin, 1995 & $\begin{array}{lr}\text { Survey i.e. } & \text { mailed } \\
\text { questionnaire } & \text { and } \\
\text { random sample } & \\
\end{array}$ & $\begin{array}{l}\text { Banks and corporate } \\
\text { customers }\end{array}$ & Financial service & N/A \\
\hline $\begin{array}{l}\text { Kumar et al., } \\
1995\end{array}$ & $\begin{array}{l}\text { Survey and random } \\
\text { sample }\end{array}$ & $\begin{array}{l}\text { Large manufacturers } \\
\text { and small regional new } \\
\text { car dealers }\end{array}$ & Automobile & $\begin{array}{l}\text { Trust, commitment, } \\
\text { willingness to invest }\end{array}$ \\
\hline $\begin{array}{l}\text { Bejou et al., } \\
1996\end{array}$ & $\begin{array}{l}\text { Survey i.e. questionnaire, } \\
\text { random sample and } \\
\text { telephone interviews }\end{array}$ & $\begin{array}{l}\text { Sales people and retail } \\
\text { customers }\end{array}$ & Financial service & Trust, satisfaction \\
\hline $\begin{array}{l}\text { Menon et al., } \\
1996\end{array}$ & $\begin{array}{l}\text { Mailed survey letter and } \\
\text { questionnaire }\end{array}$ & $\begin{array}{l}\text { Intraorganizational } \\
\text { relationships }\end{array}$ & $\begin{array}{l}\text { Busines/ } \\
\text { organisation }\end{array}$ & N/A \\
\hline Leuthesser, 1997 & $\begin{array}{l}\text { Questionnaire } \\
\text { random sample }\end{array}$ & Supplier to buyer (B2B) & various businesses & Trust, satisfaction \\
\hline $\begin{array}{l}\text { Doney } \& \\
\text { Cannon, } 1997\end{array}$ & $\begin{array}{l}\text { Mailed questionnaire and } \\
\text { random sample }\end{array}$ & Supplier to buyer & Manufacturing & Trust \\
\hline
\end{tabular}




\begin{tabular}{|c|c|c|c|c|}
\hline $\begin{array}{l}\text { Gwinner et al., } \\
1998\end{array}$ & $\begin{array}{l}\text { In-depth } \\
\text { judgement sample and } \\
\text { Survey and random } \\
\text { sample }\end{array}$ & $\begin{array}{l}\text { Service provider and } \\
\text { customers in }\end{array}$ & various industries & N/A \\
\hline $\begin{array}{l}\text { Dorsch et al., } \\
1998\end{array}$ & $\begin{array}{l}\text { Mailed questionnaire and } \\
\text { random sample }\end{array}$ & $\begin{array}{l}\text { Vendors and purchasing } \\
\text { executies }\end{array}$ & Purchasing & $\begin{array}{l}\text { Trust, satisfaction, } \\
\text { commitment, } \\
\text { opportunism, ethics }\end{array}$ \\
\hline Smith, 1998a & Survey, random sample & $\begin{array}{l}\text { Purchasing } \\
\text { professionals and sales } \\
\text { representatives }\end{array}$ & domestic market & $\begin{array}{l}\text { Trust, satisfaction, } \\
\text { commitment }\end{array}$ \\
\hline Smith, 1998b & Survey, random sample & buyer-seller relationship & domestic market & $\begin{array}{l}\text { Trust, satisfaction, } \\
\text { commitment }\end{array}$ \\
\hline Selnes, 1998 & \begin{tabular}{l}
\multicolumn{2}{l}{ Prior telephone invitation } \\
and survey \\
questionnaire \\
random sample
\end{tabular} & $\begin{array}{l}\text { Food producer and its } \\
\text { customers }\end{array}$ & $\begin{array}{l}\text { Cafeterias and } \\
\text { Restaurants/ food } \\
\text { supply }\end{array}$ & Trust, satisfaction \\
\hline $\begin{array}{l}\text { Bowen } \quad \& \\
\text { Shoemaker, } \\
1998\end{array}$ & $\begin{array}{l}\text { survey i.e questionnaire } \\
\text { and random sample }\end{array}$ & Hotels and their guests & hotel industry & Trust, commitment \\
\hline Jap et al., 1999 & $\begin{array}{l}\text { In-depth interviews and } \\
\text { interaction data were } \\
\text { obtained from four key } \\
\text { informants }\end{array}$ & Buyers-sellers & Retail firms & Trust, Continuity \\
\hline $\begin{array}{l}\text { Baker et al., } \\
1999\end{array}$ & $\begin{array}{l}\text { Survey and convenience } \\
\text { sample }\end{array}$ & Suppliers and resellers & $\begin{array}{l}\text { Channel: various } \\
\text { industries }\end{array}$ & $\begin{array}{l}\text { Trust, satisfaction, } \\
\text { commitment }\end{array}$ \\
\hline Johnson, 1999 & $\begin{array}{l}\text { Survey i.e. questionnaire } \\
\text { and convenience sample }\end{array}$ & $\begin{array}{l}\text { Suppliers } \\
\text { distributors } \\
\text { (buyer-seller) }\end{array}$ & $\begin{array}{l}\text { Industrial } \\
\text { machinery } \\
\text { equipment } \\
\text { distribution }\end{array}$ & Trust, fairness \\
\hline $\begin{array}{l}\text { Garbarino } \& \\
\text { Johnson, } 1999\end{array}$ & $\begin{array}{l}\text { Survey i.e. questionnaire } \\
\text { and random sample of }\end{array}$ & $\begin{array}{l}\text { Service providers and } \\
\text { consumers }\end{array}$ & customer-firm & $\begin{array}{l}\text { Trust, } \\
\text { commitment }\end{array}$ \\
\hline $\begin{array}{l}\text { Henning-Thurau } \\
, 2000\end{array}$ & $\begin{array}{l}\text { Face-to-face } \\
\text { questionnaire survey and } \\
\text { random sample }\end{array}$ & $\begin{array}{l}\text { Customers } \\
\text { manufacturers }\end{array}$ & Electronic & commitment, \\
\hline $\begin{array}{l}\text { Naude \& Buttle, } \\
2000\end{array}$ & Questionnaire & $\begin{array}{l}\text { Executives in various } \\
\text { industries and their } \\
\text { suppliers (B-to-B) }\end{array}$ & Business & $\begin{array}{l}\text { Trust, satisfaction, } \\
\text { coordination, power }\end{array}$ \\
\hline Boles et al., 2000 & $\begin{array}{l}\text { Survey i.e. questionnaire } \\
\text { and random sample }\end{array}$ & Business to business & Business & Trust, satisfaction \\
\hline $\begin{array}{l}\text { Scanlan \& } \\
\text { McPhail, 2000 }\end{array}$ & $\begin{array}{l}\text { Exploratory i.e. in-depth } \\
\text { interview and descriptive } \\
\text { research i.e. survey and } \\
\text { convenient sampling }\end{array}$ & $\begin{array}{l}\text { Business travellers and } \\
\text { hotel receptionists }\end{array}$ & Hospitality & Satisfaction \\
\hline $\begin{array}{l}\text { Hibbard et al., } \\
2001\end{array}$ & Mailed questionnaire & $\begin{array}{l}\text { Manufacturers and their } \\
\text { independent dealers }\end{array}$ & Market channel & Trust, commitment \\
\hline $\begin{array}{l}\text { Goodman } \\
\text { Dion, } 2001\end{array}$ & Mailed questionnaire & $\begin{array}{l}\text { Distributor-manufacture } \\
\mathrm{r}\end{array}$ & $\begin{array}{l}\text { Industrial } \\
\text { distribution } \\
\text { channel }\end{array}$ & Commitment \\
\hline $\begin{array}{l}\text { De Ruyeter et } \\
\text { al., 2001 }\end{array}$ & $\begin{array}{l}\text { Indepth interview and } \\
\text { questionnaire }\end{array}$ & Business to business & Technology & Trust, commitment \\
\hline $\begin{array}{l}\text { Hewett et al., } \\
2002\end{array}$ & $\begin{array}{l}\text { Questionnaire } \\
\text { convenient sample }\end{array}$ & buyer-seller & Industrial & N/A \\
\hline $\begin{array}{lll}\text { Woo } & \& & \text { Cha } \\
2002 & & \end{array}$ & Questionnaire & $\begin{array}{l}\text { Service provider } \\
\text { hotels and guests }\end{array}$ & Tourism/hotel & Trust, satisfaction \\
\hline $\begin{array}{l}\text { Henning-Thurau } \\
\text { et al., } 2002\end{array}$ & Questionnaire & $\begin{array}{l}\text { Customers-services } \\
\text { business }\end{array}$ & Service business & $\begin{array}{l}\text { Trust, } \\
\text { commitment }\end{array}$ \\
\hline $\begin{array}{l}\text { Wong \& Sohal, } \\
\text { 2002a }\end{array}$ & Questionnaire & $\begin{array}{l}\text { Department store and } \\
\text { retail shoppers }\end{array}$ & Retail & N/A \\
\hline $\begin{array}{l}\text { Wong \& Sohal, } \\
2002 \mathrm{~b}\end{array}$ & Questionnaire & Employee and company & Retail & $\begin{array}{l}\text { Trust, } \text { satisfaction, } \\
\text { commitment, quality }\end{array}$ \\
\hline $\begin{array}{l}\text { Friman et al., } \\
2002\end{array}$ & Case study & $\begin{array}{l}\text { Business to business i.e. } \\
\text { service firms and } \\
\text { international partners }\end{array}$ & $\begin{array}{l}\text { International } \\
\text { business }\end{array}$ & Trust, commitment \\
\hline $\begin{array}{l}\text { Lang \& Colgate, } \\
2003\end{array}$ & $\begin{array}{lr}\text { Stratified } & \text { probability } \\
\text { sampling } & \text { and } \\
\text { questionnaire } & \\
\end{array}$ & $\begin{array}{l}\text { Financial service } \\
\text { providers (banks) and } \\
\text { online retail customers }\end{array}$ & $\begin{array}{l}\text { Information } \\
\text { technology }\end{array}$ & $\begin{array}{l}\text { Trust, satisfaction, } \\
\text { commitment, bond }\end{array}$ \\
\hline $\begin{array}{l}\text { Keating et al., } \\
2003\end{array}$ & $\begin{array}{l}\text { Focus groups and an } \\
\text { online survey and } \\
\text { convenient sampling }\end{array}$ & Online retailing & Online retail & $\begin{array}{l}\text { Trust, communication, } \\
\text { understanding, value }\end{array}$ \\
\hline $\begin{array}{l}\text { Walter et al., } \\
2003\end{array}$ & Supplier-customer & $\begin{array}{lr}\begin{array}{l}\text { Manufacturing } \\
\text { and supplier } \\
\text { professional, } \\
\text { purchasing } \\
\text { industries }\end{array} \\
\end{array}$ & Various industries & $\begin{array}{l}\text { Trust, satisfaction, } \\
\text { commitment }\end{array}$ \\
\hline Roberts et al., & Questionnaire & Service firms and their & Various & satisfaction, \\
\hline
\end{tabular}




\begin{tabular}{|c|c|c|c|c|}
\hline 2003 & & customers & industries & commitment \\
\hline $\begin{array}{l}\text { Sanzo et al., } \\
2003\end{array}$ & Questionnaire & $\begin{array}{l}\text { Buyer-seller } \\
\text { Industrial firms } \\
\text { suppliers }\end{array}$ & Industrial & Trust, conflict, value \\
\hline $\begin{array}{l}\text { Woo \& Ennew, } \\
2004\end{array}$ & Questionnaire & B-to-B relationships & $\begin{array}{l}\text { Professional } \\
\text { services } \\
\text { (consulting } \\
\text { engineering } \\
\text { services) }\end{array}$ & Adaptation, cooperation \\
\hline $\begin{array}{l}\text { Fynes et al., } \\
2004\end{array}$ & $\begin{array}{l}\text { Mailed questionnaire and } \\
\text { convenience sampling }\end{array}$ & $\begin{array}{ll}\begin{array}{l}\text { Supply } \\
\text { relationship }\end{array} & \text { chain } \\
\end{array}$ & Manufacturing & $\begin{array}{l}\text { Trust, communication, } \\
\text { adaptation, cooperation }\end{array}$ \\
\hline $\begin{array}{ll}\text { Venetis } & \& \\
\text { Ghauri, } 2004\end{array}$ & $\begin{array}{l}\text { Semi-structured } \\
\text { interview and } \\
\text { questionnaire, } \\
\text { convenience sample }\end{array}$ & $\begin{array}{l}\text { Advertising agencies } \\
\text { and business customers } \\
\text { (products and services) }\end{array}$ & Advertising & Commitment \\
\hline $\begin{array}{l}\text { Lages et al., } \\
2005\end{array}$ & $\begin{array}{l}\text { Survey i.e. questionnaire } \\
\text { and convenience sample }\end{array}$ & Exporters - importers & Export market & $\begin{array}{l}\text { Satisfaction, } \\
\text { communication }\end{array}$ \\
\hline $\begin{array}{l}\text { Bennett } \& \\
\text { Barkensjo, } 2005\end{array}$ & $\begin{array}{l}\text { Survey i.e. interview and } \\
\text { questionnaire } \\
\text { convenience sample }\end{array}$ & $\begin{array}{l}\text { Charities and their } \\
\text { beneficiaries }\end{array}$ & Charity & Trust, commitment \\
\hline $\begin{array}{l}\text { Farrelly } \& \\
\text { Quester, } 2005\end{array}$ & $\begin{array}{l}\text { Survey i.e. interview and } \\
\text { questionnaire and } \\
\text { convenience sample }\end{array}$ & $\begin{array}{lr}\begin{array}{l}\text { Football } \\
\text { (Australian }\end{array} & \begin{array}{r}\text { teams } \\
\text { Football } \\
\text { League) and } \\
\text { sponsors }\end{array} \\
\end{array}$ & Sport & Trust, commitment \\
\hline $\begin{array}{l}\text { Van Bruggen et } \\
\text { al., } 2005\end{array}$ & $\begin{array}{l}\text { Survey i.e. mailed } \\
\text { questionnaire } \\
\text { convenience sample }\end{array}$ & $\begin{array}{l}\text { B-to-B relationships } \\
\text { Professional painters } \\
\text { (owners/heads r of } \\
\text { painting firms) and } \\
\text { distributors of paints }\end{array}$ & $\begin{array}{l}\text { Channel } \\
\text { distribution }\end{array}$ & $\begin{array}{l}\text { Trust, commitment, } \\
\text { satisfaction, conflict }\end{array}$ \\
\hline Huntley, 2006 & $\begin{array}{l}\text { Telephone survey and } \\
\text { convenience sampling }\end{array}$ & Buyer-seller & Technology & Trust, commitment \\
\hline $\begin{array}{l}\text { Athanasopoulou, } \\
2006\end{array}$ & $\begin{array}{l}\text { Case study, indepth } \\
\text { interview and document } \\
\text { review }\end{array}$ & $\begin{array}{lr}\text { Corporate } & \text { customers } \\
\text { and financial } & \text { service } \\
\text { providers } & \text { (leasing } \\
\text { services) } & \\
\end{array}$ & $\begin{array}{l}\text { Corporate } \\
\text { financial service }\end{array}$ & N/A \\
\hline $\begin{array}{l}\text { Park \& Deitz, } \\
2006\end{array}$ & $\begin{array}{l}\text { Survey, convenience } \\
\text { sample }\end{array}$ & $\begin{array}{l}\text { Automobile } \\
\text { manufacturers and their } \\
\text { salespeople }\end{array}$ & Automobile & Satisfaction \\
\hline $\begin{array}{l}\text { Ramaseshan et } \\
\text { al., } 2006\end{array}$ & $\begin{array}{l}\text { Survey i.e. questionnaire } \\
\text { and random sample }\end{array}$ & $\begin{array}{l}\text { Department stores and } \\
\text { their tenants }\end{array}$ & $\begin{array}{l}\text { Distribution } \\
\text { channel }\end{array}$ & $\begin{array}{l}\text { Satisfaction, } \\
\text { commitment }\end{array}$ \\
\hline $\begin{array}{l}\text { Ulaga \& Eggert, } \\
2006\end{array}$ & $\begin{array}{l}\text { Depth-interview and } \\
\text { mailed questionnaire }\end{array}$ & $\begin{array}{l}\text { Industrial purchasing } \\
\text { managers and vendors - } \\
\text { various industries }\end{array}$ & Manufacturing & $\begin{array}{l}\text { Trust, commitment, } \\
\text { satisfaction }\end{array}$ \\
\hline $\begin{array}{l}\text { Leonidou et al., } \\
2006\end{array}$ & $\begin{array}{lr}\text { Random } & \text { i.e. } \\
\text { questionnaire } & \text { and } \\
\text { systematic sample } & \end{array}$ & $\begin{array}{l}\text { US exporters and } \\
\text { importer }\end{array}$ & Industrial export & $\begin{array}{l}\text { Trust, commitment, } \\
\text { satisfaction, } \\
\text { cooperation, } \\
\text { communication }\end{array}$ \\
\hline Carr, 2006 & Interview & $\begin{array}{l}\text { IS departments and IS } \\
\text { users }\end{array}$ & $\begin{array}{l}\text { Information } \\
\text { systems }\end{array}$ & $\begin{array}{l}\text { Trust, } \\
\text { commitment }\end{array}$ \\
\hline Ndubisi, 2006 & $\begin{array}{l}\text { Survey i.e. questionnaire } \\
\text { and convenience sample }\end{array}$ & $\begin{array}{ll}\begin{array}{l}\text { Banks and retail } \\
\text { customers }\end{array} & \\
\end{array}$ & Banking & $\begin{array}{l}\text { Trust, } \\
\text { commitment }\end{array}$ \\
\hline $\begin{array}{l}\text { Naudé et al., } \\
2007\end{array}$ & Questionnaire & Manager to manager & $\begin{array}{l}\text { Business } \\
\text { business }\end{array}$ & N/A \\
\hline $\begin{array}{ll}\text { Rauyruen } & \& \\
\text { Miller, } 2007 & \\
\end{array}$ & $\begin{array}{l}\text { Mail and online survey; } \\
\text { convenience sample }\end{array}$ & Business to business & $\begin{array}{l}\text { Courier Delivery } \\
\text { services }\end{array}$ & N/A \\
\hline $\begin{array}{l}\text { Prinsloo et al., } \\
2007\end{array}$ & $\begin{array}{l}\text { Internal mail system } \\
\text { questionnaire }\end{array}$ & Inter-functional & $\begin{array}{l}\text { Small-medium } \\
\text { size marketer }\end{array}$ & N/A \\
\hline $\begin{array}{l}\text { Shabbir et al., } \\
2007\end{array}$ & $\begin{array}{l}\text { Semi-structured } \\
\text { interview }\end{array}$ & & & N/A \\
\hline $\begin{array}{l}\text { Beatson et al., } \\
2008\end{array}$ & $\begin{array}{l}\text { Self-completed } \\
\text { questionnaire }\end{array}$ & $\begin{array}{l}\text { Business and } \\
\text { leisure travellers }\end{array}$ & Tourism & $\begin{array}{l}\text { Satisfaction, trust, and } \\
\text { commitment }\end{array}$ \\
\hline $\begin{array}{ll}\text { Ibrahim } & \& \\
\text { Najjar, 2008 } & \\
\end{array}$ & Questionnaire & Retailer-customer & Retail & N/A \\
\hline $\begin{array}{l}\text { Kilburn } \quad \& \\
\text { Kilburn, } 2008\end{array}$ & Online questionnaire & $\begin{array}{l}\text { internal } \\
\text { customers and suppliers }\end{array}$ & organisation & N/A \\
\hline $\begin{array}{l}\text { Skarmeas } \& \\
\text { Robson, 2008 }\end{array}$ & Mailed questionnaire & $\begin{array}{l}\text { Importers and foreign } \\
\text { suppliers }\end{array}$ & $\begin{array}{l}\text { International } \\
\text { business }\end{array}$ & N/A \\
\hline $\begin{array}{l}\text { Hsin Hsin \& Po } \\
\text { Wen, } 2009\end{array}$ & $\begin{array}{l}\text { questionnaire, case study } \\
\text { and interview }\end{array}$ & & & $\begin{array}{l}\text { satisfaction, trust, and } \\
\text { commitment }\end{array}$ \\
\hline $\begin{array}{l}\text { Morry \& Kito, } \\
2009\end{array}$ & Questionnaire & self-friend relationship & interpersonal & N/A \\
\hline Vieira, 2009 & Questionnaire & Business to business & Hotel & N/A \\
\hline Vesel \& Zabkar, & Telephone interviews & Retail relationship & Retail & Trust, commitment and \\
\hline
\end{tabular}




\begin{tabular}{|c|c|c|c|c|}
\hline 2010 & & & & satisfaction \\
\hline $\begin{array}{l}\text { Knobloch \& } \\
\text { Knobloch-Fe dde } \\
\text { rs, 2010 }\end{array}$ & Questionnaire & $\begin{array}{l}\text { Actor-partner } \\
\text { interdependence }\end{array}$ & Couple & N/A \\
\hline Al-alak, 2010 & Questionnaire & N/A & $\begin{array}{l}\text { Health and fitness } \\
\text { setting }\end{array}$ & N/A \\
\hline $\begin{array}{l}\text { Canevello \& } \\
\text { Crocker, 2010 }\end{array}$ & Questionnaire & $\begin{array}{l}\text { Interpersonal } \\
\text { relationship }\end{array}$ & $\begin{array}{l}\text { Human } \\
\text { relationship }\end{array}$ & N/A \\
\hline $\begin{array}{l}\text { Cannière et al., } \\
2010\end{array}$ & Questionnaire & Customer-firm & Retail & N/A \\
\hline $\begin{array}{l}\text { Cater \& Cater, } \\
2010\end{array}$ & $\begin{array}{l}\text { Email and web based } \\
\text { questionnaire. }\end{array}$ & Business-to-business & Manufacturing & N/A \\
\hline $\begin{array}{l}\text { Morry et al., } \\
2010\end{array}$ & Questionnaire & Self- versus partner & $\begin{array}{l}\text { Human } \\
\text { relationship }\end{array}$ & trait, perception, \\
\hline Park et al., 2010 & Questionnaire & & Industrial selling & N/A \\
\hline $\begin{array}{l}\text { Barry \& Doney, } \\
2011\end{array}$ & $\begin{array}{l}\text { Exploratory re- } \\
\text { search, pretesting, and } \\
\text { final survey administra- } \\
\text { tion }\end{array}$ & $\begin{array}{l}\text { Suppliers and } \\
\text { retailer }\end{array}$ & $\begin{array}{l}\text { Industrial service } \\
\text { marketing }\end{array}$ & $\begin{array}{l}\text { Satisfaction, trust, and } \\
\text { commitment }\end{array}$ \\
\hline Clark et al., 2011 & Online questionnaire & $\begin{array}{lr}\text { physician and } & \text { the } \\
\text { pharmaceutical } & \text { sales } \\
\text { representative } & \\
\end{array}$ & $\begin{array}{l}\text { Medical } \\
\text { marketing }\end{array}$ & $\begin{array}{l}\text { Relationship benefits, } \\
\text { relationship investment, } \\
\text { relational dependences }\end{array}$ \\
\hline $\begin{array}{l}\text { Gentzler et al., } \\
2011\end{array}$ & On-line questionnare & Parental relationship & Parenting & Communication \\
\hline Hunt et al., 2011 & Questionnaire & $\begin{array}{l}\text { Financial planners and } \\
\text { clients }\end{array}$ & Financial sector & N/A \\
\hline $\begin{array}{l}\text { Keating et al., } \\
2011\end{array}$ & Online questionnaire & Customer to business & $\begin{array}{l}\text { Online banking } \\
\text { service }\end{array}$ & Service delivery, loyalty \\
\hline $\begin{array}{l}\text { Liang et al., } \\
2011\end{array}$ & Questionnaire & $\begin{array}{l}\text { User's social sharing } \\
\text { and social shopping }\end{array}$ & E-commerce & N/A \\
\hline $\begin{array}{l}\text { Petrican et al., } \\
2011\end{array}$ & Questionnaire & Partner-couple & & N/A \\
\hline $\begin{array}{l}\text { Weigel et al., } \\
2011\end{array}$ & Questionnaire & $\begin{array}{l}\text { Individuals in romantic } \\
\text { relationships }\end{array}$ & & N/A \\
\hline Vikas, 2011 & Structured questionnaire & $\begin{array}{l}\text { Customers and service } \\
\text { providers }\end{array}$ & Telecoms & N/A \\
\hline $\begin{array}{l}\text { Zhang et al., } \\
2011\end{array}$ & Questionnaire & $\begin{array}{l}\text { Information systems } \\
\text { professionals and online } \\
\text { customer }\end{array}$ & Online & N/A \\
\hline $\begin{array}{l}\text { Chu \& Wang, } \\
2012\end{array}$ & Questionnaire & $\begin{array}{l}\text { Company-third party } \\
\text { logistics providers }\end{array}$ & Supply chain & N/A \\
\hline $\begin{array}{l}\text { Ndubisi et al., } \\
2012\end{array}$ & Questionnaire & $\begin{array}{l}\text { Retail banking and } \\
\text { customer }\end{array}$ & Retail banking & N/A \\
\hline Vidal, 2012 & Questionnaire & Supplier-retailer & $\begin{array}{l}\text { Industrial } \\
\text { distribution } \\
\text { context }\end{array}$ & N/A \\
\hline Yen et al., 2012 & Questionnaire & $\begin{array}{l}\text { Life insurance service } \\
\text { provider and customer }\end{array}$ & & N/A \\
\hline $\begin{array}{l}\text { Zimmerman \& } \\
\text { Roberts, } 2012\end{array}$ & Questionnaire & Couple & $\begin{array}{l}\text { Marriage } \\
\text { relationship }\end{array}$ & N/A \\
\hline $\begin{array}{l}\text { Ahamed } \quad \& \\
\text { Skallerud, } 2013\end{array}$ & Questionnaires & Business to business. & $\begin{array}{l}\text { Garment-exportin } \\
\text { g firms }\end{array}$ & N/A \\
\hline $\begin{array}{l}\text { Bellavance et al., } \\
2013\end{array}$ & Questionnaire & $\begin{array}{l}\text { Superior-manager } \\
\text { relationship }\end{array}$ & Organisation & N/A \\
\hline $\begin{array}{l}\text { Brouer et al., } \\
2013\end{array}$ & Questionnaire & $\begin{array}{l}\text { Unit leader-staff } \\
\text { personnel relationship }\end{array}$ & Academic/ school & N/A \\
\hline $\begin{array}{l}\text { Kühne, et al., } \\
2013\end{array}$ & Questionnaire & $\begin{array}{l}\text { Relationship between } \\
\text { chain members }\end{array}$ & Food chain & N/A \\
\hline Kang et al., 2013 & $\begin{array}{l}\text { Face-to-face interview } \\
\text { and questionnaire }\end{array}$ & Business & Food & N/A \\
\hline $\begin{array}{l}\text { Leonidou et al., } \\
2013\end{array}$ & questionnaire & $\begin{array}{l}\text { exporter-importer } \\
\text { relationship }\end{array}$ & $\begin{array}{l}\text { international } \\
\text { business }\end{array}$ & $\begin{array}{l}\text { cooperation, } \\
\text { communication, trust, } \\
\text { and commitment }\end{array}$ \\
\hline Lin, 2013 & Questionnaires & $\begin{array}{l}\text { Customers and their } \\
\text { service provider }\end{array}$ & & Trust and satisfaction \\
\hline Marquardt, 2013 & Questionnaire & $\begin{array}{l}\text { Buyer-seller } \\
\text { relationships }\end{array}$ & Industrial & N/A \\
\hline $\begin{array}{l}\text { Omilion-Hodges } \\
\& \text { Baker, } 2013\end{array}$ & Questionnaire & Individual-leader & $\begin{array}{l}\text { Organisation/wor } \\
\mathrm{k} \text { place }\end{array}$ & N/A \\
\hline Rafiq et al., 2013 & Online questionnaire & $\begin{array}{l}\text { retailer and online } \\
\text { grocery shoppers }\end{array}$ & $\begin{array}{l}\text { Internet } \\
\text { retailing/e-grocer } \\
\mathrm{y}\end{array}$ & $\begin{array}{l}\text { Satisfaction, } \\
\text { commitment, trust }\end{array}$ \\
\hline Rašković et al., & Email and web based & buyer-supplier & industrial & N/A \\
\hline
\end{tabular}




\begin{tabular}{|c|c|c|c|c|}
\hline 2013 & questionnaire. & relationships & procurement & \\
\hline $\begin{array}{l}\text { Tareque } \text { Aziz \& } \\
\text { Azila Mohd } \\
\text { Noor, 2013 }\end{array}$ & Questionnaire & $\begin{array}{l}\text { Retailer-supplier } \\
\text { relationship }\end{array}$ & Retail & N/A \\
\hline $\begin{array}{l}\text { Tung \& Carlson, } \\
2013\end{array}$ & Questionnaire & $\begin{array}{l}\text { Retail banking and } \\
\text { customer }\end{array}$ & Banking industry & N/A \\
\hline $\begin{array}{l}\text { Tripathi \& Dave, } \\
2013\end{array}$ & Questionnaire & Customer-retail & Retail & N/A \\
\hline Ying-Pin, 2013 & Questionnaire & Suppliers and retailers & $\begin{array}{l}\text { Automobile } \\
\text { industry }\end{array}$ & $\begin{array}{l}\text { Commitment, } \\
\text { cooperation, trust, } \\
\text { satisfaction, } \\
\text { coordination, adaptation }\end{array}$ \\
\hline Akrout, 2014 & $\begin{array}{l}\text { Semi-structured } \\
\text { interview }\end{array}$ & Business to business & & N/A \\
\hline Al-Alak, 2014 & Questionnaire & Banks-client & & N/A \\
\hline Atrek et al., 2014 & $\begin{array}{l}\text { Semi-structured } \\
\text { interview }\end{array}$ & $\begin{array}{l}\text { Business to business i.e } \\
\text { Company \& supplier }\end{array}$ & Supply chain & $\begin{array}{l}\text { Service performance, } \\
\text { service quality, product } \\
\text { quality }\end{array}$ \\
\hline $\begin{array}{l}\text { Giota } \quad \text { and } \\
\text { Kleftaras, } 2014\end{array}$ & Questionnaire & Facebook users & $\begin{array}{l}\text { Online social } \\
\text { media }\end{array}$ & N/A \\
\hline $\begin{array}{l}\text { Huang et al, } \\
2014\end{array}$ & $\begin{array}{l}\text { Online interview, web } \\
\text { link and questionnaire }\end{array}$ & Online customer - buyer & $\begin{array}{l}\text { Online market/ } \\
\text { buying }\end{array}$ & N/A \\
\hline Lai, 2014 & Questionnaire & Business to customer & $\begin{array}{l}\text { Travel agency } \\
\text { industry }\end{array}$ & $\begin{array}{lr}\begin{array}{l}\text { Service quality } \\
\text { perceived value }\end{array} \\
\begin{array}{l}\text { antecedents } \\
\text { relationship quality }\end{array} \\
\end{array}$ \\
\hline Lo \& Im, 2014 & $\begin{array}{ll}\text { Questionnaire } & \text { and } \\
\text { in-depth interviews } & \end{array}$ & $\begin{array}{l}\text { Hotel staff and } \\
\text { customers }\end{array}$ & Hotel industry & N/A \\
\hline $\begin{array}{l}\text { Nguyen } \& \\
\text { Nguyen, } 2014\end{array}$ & Questionnaire & Business & Export & N/A \\
\hline $\begin{array}{l}\text { Subramony, } \\
2014\end{array}$ & Questionnaire & Firm-client & Business & N/A \\
\hline $\begin{array}{l}\text { Semrau } \\
\text { Werner, } 2014\end{array}$ & Interview & Network relationship & Business network & N/A \\
\hline $\begin{array}{l}\text { Uchino et al., } \\
2014\end{array}$ & Questionnaire & spousal relationships & $\begin{array}{l}\text { marriage } \\
\text { relationship }\end{array}$ & N/A \\
\hline $\begin{array}{l}\text { Ahamed et al., } \\
2015\end{array}$ & Questionnaires & Business to business & Exporting firms & N/A \\
\hline $\begin{array}{l}\text { Hoppner et al., } \\
2015\end{array}$ & Mailed questionnaire & Business to business & Business & N/A \\
\hline $\begin{array}{l}\text { Itani \& Inyang, } \\
2015\end{array}$ & Questionnaire & Sales person to customer & Retail banking & N/A \\
\hline Sheu, 2015 & $\begin{array}{l}\text { Face-to-face interview } \\
\text { and questionnaire }\end{array}$ & $\begin{array}{l}\text { Producer-dealer } \\
\text { distribution channels }\end{array}$ & $\begin{array}{l}\text { Distribution } \\
\text { channels }\end{array}$ & N/A \\
\hline $\begin{array}{l}\text { Williams et al., } \\
2015\end{array}$ & Questionnaires & Business/firm & $\begin{array}{l}\text { Project } \\
\text { management }\end{array}$ & N/A \\
\hline
\end{tabular}

\section{Copyrights}

Copyright for this article is retained by the author(s), with first publication rights granted to the journal.

This is an open-access article distributed under the terms and conditions of the Creative Commons Attribution license (http://creativecommons.org/licenses/by/4.0/). 